NASA/TM-2014-218494

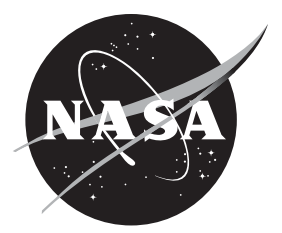

\title{
Computational Investigation of Novel Tip Leakage Mitigation Methods for High Pressure Turbine Blades
}

Mounir Ibrahim and Abhinav Gupta

Cleveland State University, Cleveland, Ohio

Vikram Shyam

Glenn Research Center, Cleveland, Ohio 


\section{NASA STI Program . . . in Profile}

Since its founding, NASA has been dedicated to the advancement of aeronautics and space science. The NASA Scientific and Technical Information (STI) program plays a key part in helping NASA maintain this important role.

The NASA STI Program operates under the auspices of the Agency Chief Information Officer. It collects, organizes, provides for archiving, and disseminates NASA's STI. The NASA STI program provides access to the NASA Aeronautics and Space Database and its public interface, the NASA Technical Reports Server, thus providing one of the largest collections of aeronautical and space science STI in the world. Results are published in both non-NASA channels and by NASA in the NASA STI Report Series, which includes the following report types:

- TECHNICAL PUBLICATION. Reports of completed research or a major significant phase of research that present the results of NASA programs and include extensive data or theoretical analysis. Includes compilations of significant scientific and technical data and information deemed to be of continuing reference value. NASA counterpart of peer-reviewed formal professional papers but has less stringent limitations on manuscript length and extent of graphic presentations.

- TECHNICAL MEMORANDUM. Scientific and technical findings that are preliminary or of specialized interest, e.g., quick release reports, working papers, and bibliographies that contain minimal annotation. Does not contain extensive analysis.

- CONTRACTOR REPORT. Scientific and technical findings by NASA-sponsored contractors and grantees.
- CONFERENCE PUBLICATION. Collected papers from scientific and technical conferences, symposia, seminars, or other meetings sponsored or cosponsored by NASA.

- SPECIAL PUBLICATION. Scientific, technical, or historical information from NASA programs, projects, and missions, often concerned with subjects having substantial public interest.

- TECHNICAL TRANSLATION. Englishlanguage translations of foreign scientific and technical material pertinent to NASA's mission.

Specialized services also include creating custom thesauri, building customized databases, organizing and publishing research results.

For more information about the NASA STI program, see the following:

- Access the NASA STI program home page at http://www.sti.nasa.gov

- E-mail your question to help@sti.nasa.gov

- Fax your question to the NASA STI Information Desk at 443-757-5803

- Phone the NASA STI Information Desk at 443-757-5802

- Write to: STI Information Desk NASA Center for AeroSpace Information 7115 Standard Drive Hanover, MD 21076-1320 
NASA/TM-2014-218494

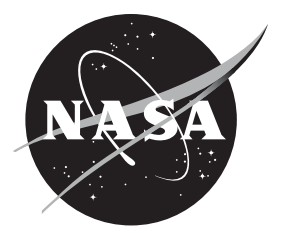

\section{Computational Investigation of Novel Tip Leakage Mitigation Methods for High Pressure Turbine Blades}

Mounir Ibrahim and Abhinav Gupta

Cleveland State University, Cleveland, Ohio

Vikram Shyam

Glenn Research Center, Cleveland, Ohio

Prepared for the

50th Joint Propulsion Conference

cosponsored by AIAA, ASME, SAE, and ASEE

Cleveland, Ohio, July 28-30, 2014

National Aeronautics and

Space Administration

Glenn Research Center

Cleveland, Ohio 44135 


\section{Acknowledgments}

Part of this work was conducted by the lead author while he was a Summer Fellow at the NASA Glenn Research Center and with Dr. Shyam as the NASA colleage. NASA Glenn is greatly acknowledeged for such support. We greatly appreciate the computer time provided for us by the Ohio Super Computer (OSC). The OSC Computer Cluster has been made available as part of the Center's mission to support Ohio Universities.

Trade names and trademarks are used in this report for identification only. Their usage does not constitute an official endorsement, either expressed or implied, by the National Aeronautics and Space Administration.

This work was sponsored by the Fundamental Aeronautics Program at the NASA Glenn Research Center.

Level of Review: This material has been technically reviewed by technical management.

Available from

NASA Center for Aerospace Information 7115 Standard Drive

Hanover, MD 21076-1320
National Technical Information Service 5301 Shawnee Road Alexandria, VA 22312 


\title{
Computational Investigation of Novel Tip Leakage Mitigation Methods for High Pressure Turbine Blades
}

\author{
Mounir Ibrahim and Abhinav Gupta \\ Cleveland State University \\ Cleveland, Ohio 44115 \\ Vikram Shyam \\ National Aeronautics and Space Administration \\ Glenn Research Center \\ Cleveland, Ohio 44135
}

\begin{abstract}
This paper presents preliminary findings on a possible approach to reducing tip leakage losses. In this paper a computational study was conducted on the Energy Efficient Engine (EEE) High Pressure Turbine (HPT) rotor tip geometry using the commercial numerical solver ANSYS FLUENT. The flow solver was validated against aerodynamic data acquired in the NASA Transonic Turbine Blade Cascade facility. The scope of the ongoing study is to computationally investigate how the tip leakage and overall blade losses are affected by (1) injection from the tip near the pressure side, (2) injection from the tip surface at the camber line, and (3) injection from the tip surface into the tip separation bubble. The objective is to identify the locations on the tip surface at which to place appropriately configured blowing keeping in mind the film cooling application of tip blowing holes. The validation was conducted at Reynolds numbers of 85,000,343,000, and 685,000 and at engine realistic flow conditions. The coolant injection simulations were conducted at a Reynolds number of 343,000 based on blade chord and inlet velocity and utilized the SST turbulence model in FLUENT. The key parameters examined are the number of jets, jet angle and jet location. A coolant to inlet pressure ratio of 1.0 was studied for angles of $+30^{\circ},-30^{\circ}$, and $90^{\circ}$ to the local free stream on the tip. For the 3 hole configuration, 3 holes spaced 3 hole diameters apart with length to diameter ratio of 1.5 were used. A simulation including 11 holes along the entire mean camber line is also presented ( $30^{\circ}$ toward suction side). In addition, the effect of a single hole is also compared to a flat tip with no injection. The results provide insight into tip flow control methods and can be used to guide further investigation into tip flow control. As noted in past research it is concluded that reducing leakage flow is not necessarily synonymous with reducing losses due to leakage.
\end{abstract}

\section{Nomenclature}

$C_{p} \quad 2\left(P_{T}-P\right) / \rho U_{e}^{2}$, pressure coefficient

Cx blade axial chord $(132.59 \mathrm{~mm})$

$P$ pressure

$P_{S} \quad$ upstream static pressure

$P_{T} \quad$ upstream stagnation pressure

Re Reynolds number based on inlet conditions and axial chord

$U_{e} \quad$ nominal exit freestream velocity, based on inviscid solution

$\mathrm{Z} \quad$ spanwise coordinate

$\mathrm{X}$ axial coordinate, axial distance from leading edge

Y pitchwise coordinate

$\rho \quad$ density

$\psi \quad\left(P_{T^{-}} P_{T e}\right) /\left(P_{T^{-}} P_{S}\right)$, total pressure loss coefficient 


\section{Introduction}

NASA's N+3 notional engines are expected to be characterized by high operating pressure ratios and turbine inlet total temperatures. The more compact highly loaded turbines will result in large pressure difference across the turbine rotor tips. The pressure distribution set up around the rotor blade results in a pressure gradient across the tip gap of the rotor. This is a significant concern due to the occurrence of aerodynamic loss due to tip leakage. The high pressure gas on the pressure side of the blade has a tendency to flow towards the suction side, which is at a lower pressure, across the tip. The path of the tip flow depends on several parameters such as blade rotational rate, blade geometry (tapering, twist, camber, tip gap height, and tip contouring) and flow inlet angle. These parameters can be reduced to the ratio of tip width to tip gap height, tip inlet Mach number and flow direction. No matter what the cause of the leakage flow, it results in a drop in efficiency and aerodynamic loss. The loss due to the interaction of the tip leakage vortex with the passage flow comprises approximately 20 to 30 percent of the total loss in a turbine stage. It is therefore important to reduce the leakage across the tip relative to the massflow through the passage. The width-to-height ratio of the tip gap changes as the chord increases from leading edge to trailing edge. This is accompanied by a change in the flow structure in the tip gap. If one is to attempt to control the flow through the tip gap, it is important to take into account the location and extent of the separation bubble, the local flow direction and the mass flow rate per unit chord as a function of the mass flow rate through the passage. A detailed literature review of the basic features of turbine tip flow and heat transfer has been conducted by Bunker (Ref. 1) and Glezer et al. (Ref. 2). Glezer et al. (Ref. 2) describe the primary flow features seen due to tip leakage: the pressure side separation bubble on the tip surface and the tip leakage vortex. The extent of the bubble and its reattachment are contingent on blade thickness, Mach number, Reynolds number and tip height (Refs. 2 and 3). For subsonic flows, the percentage of inlet flow that constitutes the tip leakage is shown to grow linearly with tip gap height. References 1 and 2 highlight the importance of Computational Fluid Dynamics (CFD) in tip flow and heat transfer prediction due to the difficulty of conducting experimental measurements in a rotating tip gap. Ameri et al. (Ref. 4) simulated the GE-EEE (Energy Efficient Engine) high pressure turbine stage and studied the tip flow and heat transfer for a smooth tip and for a recessed tip. The cavity height of the recess was varied. Two primary vortex structures were observed in the recess. It was found that the recess had negligible effect on loss. Another study by Ameri et al. (Ref. 5) investigated the effect of upstream casing recess on tip leakage and heat transfer and found that minimal tip heat transfer occurred for a recess height that is almost equal to tip clearance. They concluded that the recess has little effect on efficiency. Hofer et al. (Ref. 6) state that neglecting the relative casing motion does not significantly alter results citing previous studies like that of Krishnababu et al. (Ref. 7). The latter studied the effect of relative casing motion on tip heat transfer and tip leakage mass flow for two different tip gap heights. They concluded that the effect of relative casing motion is diminished for larger tip gap heights due to dominant inviscid effects. The flow physics in a supersonic tip gap such as one encountered in highly loaded turbine stages is described in Shyam et al. (Refs. 8 and 9) and Wheeler et al. (Ref. 10). The importance of choking the tip gap to reduce the relative massflow through the gap is emphasized by both authors.

In the realm of tip leakage mitigation, there are numerous passive and active approaches. Passive approaches involve strategies like contouring of the tip and blowing into the tip and casing treatments. Active methods would involve real-time adjustments to the tip gap geometry or flow that can be varied based on mission conditions. This work deals with steady blowing into the tip gap and thus a brief literature review of relevant passive tip leakage control is presented. Rao et al. (Ref. 11) found through an experiment that injection into the tip of a recessed blade through 4 cooling holes reduced the losses associated with tip leakage. A coolant massflow of 0.6 percent of the passage massflow injected into the tip was found to be the global optimum as evaluated by averaged pressure loss coefficient in the wake. Couch et al. (Ref. 12) compared CFD to measurements of blowing from purge holes on the turbine blade tip. They found a strong dependence of cooling effectiveness on tip gap height. Studies of film cooling (such as Refs. 12 to 14) show the dependence of jet behavior on momentum ratio, injection angle, pitch 
and plenum conditions. Canelli et al. (Ref. 14) studied film cooling from holes in the recessed tip of a turbine blade. They simulated 3 holes near the leading edge region along the mean camber line and holes near the suction side further down the axial chord. Holes are generally placed along the mean camber line due to ease of manufacturing. It is clear that along the chord in the tip gap, the blowing ratio would change based on local conditions in the tip gap. There are several unanswered questions related to managing tip leakage using blowing. These relate to the optimal locations at which the coolant holes should be placed, the spacing of the holes, their inclination, the blowing ratio, frequency and the effect of loading (subsonic or supersonic flow) on the leakage control. Frequency is mentioned because it might be possible to modify the loss core with pulsed jets such as those used for separation control by Ibrahim et al. (Refs. 15 and 16).

This paper examines the effect of the number of holes along the mean camber line and the effect of leading edge hole inclination on leakage induced losses. While the mean camber line might not be the optimal location for leakage mitigation, the intent is to determine the influence of the holes on the leakage through the tip and on the overall pressure loss through the passage. Cooling holes are usually placed in locations in the tip region where heat transfer is high and to purge dust that might accumulate in sandy environs (Ref. 13). They are also usually inclined at $90^{\circ}$ to the tip surface and placed within squealer tips (Refs. 12 and 14). The scope of this paper is to answer the question of global impact of number of holes and of hole inclination on the overall loss across the turbine blade passage. Future investigations will look at heat transfer on the tip and the effect of blowing into the separation bubble as well as varied hole inclination along the tip as a function of chord.

\section{Numerical Methods}

The numerical simulations were conducted utilizing the finite-volume code ANSYS FLUENT (Ref. 18). For validation, cases were run at different Reynolds numbers. Table 1 shows the cascade parameters. The computational domain was based on Ibrahim et al. (Refs. 15 and 16). A correlation-based transition model proposed by Menter et al. (Ref. 18) that is available in ANSYS FLUENT V-12 as Transition-SST (4-equation) turbulence model was selected to model turbulence. Figure 1 shows the computational domain and the boundary conditions applied in this paper. The figure depicts a case with 11 jets at the tip equally spaced between a distance from 0.13 to $0.9 \mathrm{Cx}$. The number of cells used is 9.2 million with 50 cells packed in the tip gap region in the spanwise direction. The tip gap height is 2 percent of the span. The grid size used was reached from a grid indepence study that was conducted on the same blade. Convergence was established when: (1) residuals reduced below a value of $10^{-5}$, (2) no change was observed in any field results, and (3) the mass imbalance between inlet and exit to the computational domain was less than 0.01 percent.

\section{Experimental Facility and Measurements}

The results of the numerical simulations that were carried out are compared to the data of McVetta et al. (Ref. 17). The data was collected in the NASA Transonic Turbine Blade Cascade facility at the NASA John H. Glenn Research Center. The data includes the midspan total pressure at the exit plane and the exit flow angle at seven inlet flow angles. Reynolds numbers of 85,000 to 683,000 at two isentropic exit Mach numbers of 0.74 and 0.34 are reported. The survey plane at midspan was 8.6 percent axial chord downstream of the blade trailing edge plane and covered three blade passages. Blade and endwall static pressure distributions were reported for each flow condition. Table 1 shows the relevant parameters used in the cascade experiment of Reference 17.

Figure 2 shows the layout of the experiment in Reference 17. The turbulence intensities are reported to be between 0.25 and 0.4 percent. 


\section{Results and Discussion}

\section{Code Validation and Turbulence Model/Geometry Selection, No Gap}

In the validation stage, the blade was assumed to have no tip gap and the results are compared to the data from Reference 17. A symmetry plane was used at mid-span after comparison to a full span simulation that showed no benefit to the additional computational domain. Shown below are static pressure distributions for two different turbulence models (RSM and SST) at Reynolds numbers, Re, of $85,000,343,000$, and 685,000. Results at spanwise locations of $Z=50,75$, and 97.5 percent are presented. The pressure loss coefficient at a location $X=1.086 \mathrm{Cx}$ from the airfoil leading edge and at $\mathrm{Z}=50$ percent is also compared to experiment.

\section{$\operatorname{Re}=\mathbf{8 5 , 0 0 0}$}

Figures 3(a) to (c) show the static pressure coefficient plotted against dimensionless axial location, $\mathrm{X} / \mathrm{Cx}$ for $\mathrm{Z}=50,75$, and 97.5 percent respectively for $\mathrm{Re}=85,000$. The following observations were made: (1) The pressure distribution on the pressure surface of the airfoil are in close agreement with the experimental data regardless of the turbulence model used, or the $\mathrm{Z}$ location, (2) As for the suction surface the plots show some flow separation in the range of $\mathrm{X} / \mathrm{Cx}$ from 0.65 to 0.78 after that the flow reattach, (3) The two turbulence models, RSM and SST, at $Z=97.5$ percent showed flow separation as expected (there is no experimental data at that location to verify this although the wake shown in Figure 3(d) for the experiment shows a wide wake that is indicative of separation.)

Figure 3(d) shows the total pressure distribution along $\mathrm{X} / \mathrm{Cx}=1.086$ and $\mathrm{Z}=50$ percent plotted against $y /$ pitch. The two turbulence models, RSM and SST, showed smaller wake width as compared to the experimental data perhaps indicating that the SST predicted separation is local and the flow reattaches. The RSM model does not show separation and therefore has a narrow wake.

\section{Re 343,000}

Figures 4(a) to (c) show the static pressure coefficient plotted against dimensionless axial location, $\mathrm{X} / \mathrm{Cx}$ for $\mathrm{Z}=50,75$, and 97.5 percent respectively, for $\mathrm{Re}=343,000$. The following observations were made: (1) The pressure distribution on the pressure surface and the suction surface of the airfoil are in close agreement with the experimental data regardless of the turbulence model used, or the $\mathrm{Z}$ location.

Figure 4(d) shows the total pressure distribution along $\mathrm{X} / \mathrm{Cx}=1.086$ and $\mathrm{Z}=50$ percent plotted against y/pitch. All cases exhibit similar wake size and peak value with SST turbulence model showing slightly better agreement with the experimental data. The absence of separation removes any discrepancies between the models.

\section{$\operatorname{Re} 685,000$}

Figures 5(a) to (c) show the static pressure coefficient plotted against dimensionless axial location, $\mathrm{X} / \mathrm{Cx}$ for $\mathrm{Z}=50,75$, and 97.5 percent respectively, for $\mathrm{Re}=685,000$. Figure 5(d) shows the total pressure distribution along $\mathrm{X} / \mathrm{Cx}=1.086$ and $\mathrm{Z}=50$ percent plotted against $\mathrm{y} /$ pitch. The results for $\mathrm{Re}=685,000$ have similar observations shown earlier for $\operatorname{Re}=343,000$.

Figure 6 shows a plot of the loss coefficient, area averaged defined as:

$$
=\frac{P_{\text {total },} \text {, }{ }^{\text {in }}-\overline{P_{\text {total, }} \text {, exit }}}{P_{\text {total, },} \text { in }-\overline{P_{\text {static, }} \text { exit }}}
$$

for different Reynolds numbers comparing experimental data (Ref. 17) with CFD results. Figure 6 shows that both turbulence models underpredict loss at low Reynolds number $(\operatorname{Re}=85,000)$ because of their failure to predict an open separation. At higher Reynolds numbers both models show improved predictions with the SST model doing a better job. 


\section{Summary of Code Validation}

All cases examined in this section exhibit the following:

1. The static pressure distribution on the pressure surface of the airfoil is in close agreement with the experimental data regardless of the turbulence model used, or the $\mathrm{Z}$ (span-wise) location.

2. As for the suction surface, all cases exhibit similar results to the experimental data except at $\mathrm{Re}=85,000$, where the SST model shows a closed separation and the RSM model shows no separation. The experimental results suggest a wide wake that is not matched by the CFD.

3. As for the total pressure results at a location $1.086 \mathrm{Cx}$ from the leading edge, and $\mathrm{Z}=50$ percent, the two turbulence models, RSM and SST, showed good agreement with the experimental data for higher $\operatorname{Re}(343,000$ and 685,000). The wake predictions for $\mathrm{Re}=85,000$ is not as good for the following reasons: (a) Transition is expected and was not simulated well with the turbulence models, (b) The simulation did not include the boundary layer in the inlet flow, (c) The span of the blade is smaller (approximately equal to the cord length), (d) literature review indicates the difficulty in predicting the wake for transitional flows.

4. The overall conclusion is that there are good perditions of the experimental data especially at higher Re and with the SST model.

In the rest of the paper analyses will be done for $\mathrm{Re}=343,000$ using the SST turbulence model.

\section{Tip Leakage With Different Jet Configuration}

Different configurations were examined to investigate the effect of various jet configurations on the tip leakage.

The gap size is 2 percent $\mathrm{Cx}$. All jets are located at the mean camber line, $5 \mathrm{~mm}$ in diameter and with jet length/diameter ratio of 1.5. Table 2 shows three different jet configurations examined: (1) One jet located at $\mathrm{X} / \mathrm{Cx}=0.23$ measured from the leading edge, (2) Three jets equally spaced over a distance from $\mathrm{X} / \mathrm{Cx}=0.23$ to 0.69 measured from the leading edge, (3) Eleven jets equally spaced over a distance from $\mathrm{X} / \mathrm{Cx}=0.13$ to 0.9 measured from the leading edge. In addition different jet angles were examined: (a) $30^{\circ}$ minus (i.e., aiming towards the suction surface), (b) $90^{\circ}$ normal to the tip surface, (c) $30^{\circ}$ plus (i.e., aiming towards the pressure surface). The jet inlet pressure was kept equal to the inlet total pressure $(=36.942 \mathrm{kPa})$ for all cases. Accordinlgy (as will be shown later) the jet blowing ratio (based on jet exit velocity/inlet velocity) will vary from 1.0 to 2.2 depending on the number of jets, jet location and jet orination. This is expected to similaute real life situation where all jets will be supplied from one plenum.

Figures 7(a) to (c) show the static pressure coefficient, $\mathrm{Cp}$, plotted against dimensionless axial location, $\mathrm{X} / \mathrm{Cx}$ for $\mathrm{Z}=50,75$, and 97.5 percent respectively for $\mathrm{Re}=343,000$. The plots show cases with no jet, one jet at $+30^{\circ}$ and one jet at $-30^{\circ}$. The plots do not show any noticeable differences due to the jet on the static pressure and accordingly on the blade loading. The effect on the leakage and the total pressure losses are examined later.

Figures 8(a) to (c) show the static pressure coefficient plotted against dimensionless axial location, $\mathrm{X} / \mathrm{Cx}$ for $\mathrm{Z}=50,75$, and 97.5 percent span respectively for $\mathrm{Re}=343,000$. On the plots shown, cases with no Jet, three jets with $30^{\circ}$ plus and $30^{\circ}$ minus and 11 jets with $30^{\circ}$ plus.

In this section our study will focus of the following cases: (1) No jet, (2) One jet, minus $30^{\circ}$, (3) One jet, $90^{\circ}$, (4) Three jets, plus $30^{\circ}$, and (5) Eleven jets, plus $30^{\circ}$.

Figure 9(a) shows the velocity vectors colored by the velocity magnitude, in a plane normal to $\mathrm{Z}$ and mid-gap, $\operatorname{Re}=343,000$, for no jets. The plot shows the flow velocity is very high in the tip gap and in the aft 30 percent of the blade chord. Figure 9(b) shows the velocity vectors colored by the velocity magnitude, in a plane normal to $\mathrm{Z}$ and mid-gap, $\mathrm{Re}=343,000$, for one jet, minus $30^{\circ}$. The plot shows how the flow is accelerated due to the presence of the jet. This fact is responsible for having more leakage (as will be shown later). Figure 9(c) shows the velocity vectors colored by the velocity magnitude, in a 
plane normal to $\mathrm{Z}$ and mid-gap, $\mathrm{Re}=343,000$, for one jet, $90^{\circ}$. The plot shows how the flow is decelerated due to the presence of the jet. However the flow is accelerated upstream and around the jet. This fact is responsible for having more leakage (as will be shown later). Figures 9(d) and (e) show the velocity vectors colored by the velocity magnitude, in a plane normal to $\mathrm{Z}$ and mid-gap, $\mathrm{Re}=343,000$, for (3) jets, plus $30^{\circ}$ and (11) jets, plus $30^{\circ}$, respectively. The plots show how the flow is decelerated due to the presence of the jets near the leading edge to 30 percent chord region while it is accelerated in the aft region of the tip.

Figure 10(a) shows the velocity magnitude plotted versus $\mathrm{X} / \mathrm{Cx}$ at two lines: mid-distance between the blade tip and the casing, one on the pressure side (PS) and one on the suction side (SS), $\operatorname{Re}=343,000$, no jets and one jet, minus $30^{\circ}$. The vertical line shows the location of the jet. For the case of no jet, the velocity magnitude on SS side is higher that than on PS except in the range of X/Cx from 0.38 to 0.48 . In the case of one jet, the blowing ratio (jet outlet velocity/inlet velocity) is about 2 . The velocity magnitude on PS side did not change much. However on the SS side the signature of the jet is very clear with a slight decrease in the velocity magnitude.

Figure 10(b) shows the velocity magnitude plotted versus $\mathrm{X} / \mathrm{Cx}$ at two lines: mid-distance between the blade tip and the casing, one on the pressure side (PS) and one on the suction side (SS), $\operatorname{Re}=343,000$, no jets and one jet, $90^{\circ}$. The vertical line shows the location of the jet. For the case of no jet, the velocity magnitude on SS side is higher that than on PS except in the range of $\mathrm{X} / \mathrm{Cx}$ from 0.38 to 0.48 . In the case of one jet, the blowing ratio (jet outlet velocity/inlet velocity) is about 2 . The velocity magnitude on PS side did not change much. However on the SS side the signature of the jet is very clear with a decrease in the velocity magnitude down to 50 percent.

Figure 10(c) shows the velocity magnitude plotted versus $\mathrm{X} / \mathrm{Cx}$ at two lines: mid-distance between the blade tip and the casing, one on the pressure side (PS) and one on the suction side (SS), Re $=343,000$, no jets and (3) jets, plus $30^{\circ}$. The vertical lines show the location of the jets. In the case of (3) jets the blowing ratio (ratio of jet exit velocity to the inlet) of the jets (starting from the upstream) are: 1.14, 1.31, and 1.48, respectively (see Fig. 11). The velocity magnitude on PS side changed slightly. However on the SS side the signature of the (3) jets is very clear with decrease in the velocity magnitude down to close to zero.

Figure 10(d) shows the velocity magnitude plotted versus X/Cx at two lines: mid-distance between the blade tip and the casing, one on the pressure side (PS) and one on the suction side (SS), $\operatorname{Re}=343,000$, no jets and (11) jets, plus $30^{\circ}$. In the case of (11) jets the blowing ratio of the jets (starting from the upstream) are: $0.79,1.13,1.2,1.85,2.03,2.11,2.16,2.14,2.2,2.2$, and 2.2 , respectively. The velocity magnitude on the pressure side changed considerably by almost a factor of 2 reduction in the presence of the jets. On the suction side the signature of the (11) jets is very clear with considerable decrease in the velocity magnitude.

Figure 11 shows the blowing ratio for the individual holes for the 3 -jets and 11-jets cases. For the same coolant plenum pressure ratio, the blowing ratio rises from 1 near the leading edge to almost 2 near $30 \% \mathrm{Cx}$ and stays close to 2 for the remainder of the holes.

Figure 12(a) to (e) shows the total pressure contours at a plane $1.086 \mathrm{Cx}$ from the leading edge for: 12(a) No jet, 12(b) One jet, minus $30^{\circ}, 12$ (c) One jet, $90^{\circ}, 12$ (d) Three jets, plus $30^{\circ}$, and 12 (e) Eleven jets, plus $30^{\circ}$, respectively. The loss core in the leakage vortex is clearly visible as is the wake and passage vortex. Figure 12(d) shows the total pressure for the 3 hole, plus 30 case. there is a clear reduction in the loss core and a shift of the leakage vortex away from the suction side. An area average (see Fig. 16) was taken for all cases and will be compared later.

Figure 13(a) to (e) shows the static pressure contours at the blade tip and the suction side for: 12(a) No jet, 12(b) One jet, minus $30^{\circ}$, 12(c) One jet, $90^{\circ}$, 12(d) Three jets, plus $30^{\circ}$, and 12(e) Eleven jets, plus $30^{\circ}$, respectively. The areas that show low pressure (either on the tip or the suction side) indicate a momentum transfer from other regions and hence enhance the vortex structure and increase the losses. The data correlates very well with loss coefficient, area-averaged shown in Figure 16 (to be discussed below). 
Figure 14 shows the tip leakage mass flow as percent of the total inlet mass flow for (6) segments along the suction side of the gap, $\operatorname{Re}=343,000$, no jets, one jet, minus $30^{\circ}$, one jet $90^{\circ}$, three jets, plus $30^{\circ}$, and eleven jets, plus $30^{\circ}$. It is clear that a majority of the leakage flow exits the tip gap in the aft 30 percent of the blade chord. With one jet (minus $30^{\circ}$ ) there is noticeable increase in the leakage in all segments (as expected) since the jet is flowing in the same direction of the leaking flow. With one jet $\left(90^{\circ}\right)$ there is noticeable increase in the leakage in segments (1) and (4). In the case of (3) jets, plus $30^{\circ}$ a noticeable reduction in the leakage is seen in segment (4). With (11) jets, plus $30^{\circ}$ a reduction in the leakage is seen in all segments with a notable one occurring in segment (4). The largest impact seems to be from having a jet either at $90^{\circ}$ to the tip surface or blowing toward the pressure side at $30^{\circ}$. There is a shift in leakage distribution from 42 to 58 percent chord. This makes sense because the presence of one jet, while able to perhaps cause a loss in momentum of the leakage flow is unable to block or impact the leakage vortex. The leakage flow merely circumvents the jet and shifts to an aft location.

Figure 15 shows the total tip leakage mass flow as percent of the No jet case, $\operatorname{Re}=343,000$, one jet, minus $30^{\circ}$ (with 4 percent increase), one jet $90^{\circ}$ (with 4 percent decrease), three jets, plus $30^{\circ}$ (with 5 percent decrease), and eleven jets, plus $30^{\circ}$ (with 12 percent decrease). These results are consistent with what is discussed in Figure 10.

Figure 16 show loss coefficient, area averaged at $1.086 \mathrm{Cx}$ as percent of the no jet case, $\operatorname{Re}=343,000$, one jet, minus $30^{\circ}$ (with 24 percent decrease), one jet $90^{\circ}$ (with 33 percent decrease), three jets, plus $30^{\circ}$ ( 18 percent decrease), and eleven jets, plus $30^{\circ}$ (with 5 percent increase).

The low blowing ratio jets near the leading edge seem to redirect the flow in the tip toward the trailing edge and delay the mixing of the tip leakage with the suction side flow thus reducing the pressure loss coefficient. The high blowing ratio and strengthening of the loss core for the 11 jet case leads to an increase in losses. It is possible that individual plena with different pressure ratios for the aft 70 percent and for the leading edge holes would be beneficial to loss reduction. Table 3 shows a summary of all cases.

Accomplishing both reductions in the tip leakage flow and the loss coefficient, area averaged would require strategic allocation of: (1) number of jets, (2) jets location, and (3) jet angle. Blowing ratio is expected to play a role but was not included in this study.

\section{Conclusions}

The following conclusions are drawn from this investigation:

1. The turbulence model selected (SST) and the grid topology designed showed good agreement in predicting pressure distribution along the EEE blade for a wide range of Re (from 85,000 to 685,000),

2. The study was focused on $\mathrm{Re}=343,000$ and examining different jet configurations (one, three and eleven) distributed on the camber cord. Different jet angles were examined; $90^{\circ}, 30^{\circ}$ plus and $30^{\circ}$ minus.

3. With no jet about 50 percent of the mass leakage took place in the later 30 percent of the blade near the trailing edge.

4. Jets with $30^{\circ}$ minus increase the mass flow while showing a decrease in loss coefficient, area averaged. This could be attributed to the fact that jets with 30 minus will be in the same direction where the flow leakage occur thus increase the mass flow leaking. However, these jets will be able to break the tip leakage vortex and reducing its strength and thus reduce the losses.

5. On the contrary to the above, $30^{\circ}$ plus will reduce the leakage but will increase the losses.

6. A future exercise is to use some jets with 30 plus and others with 30 minus to achieve both leakage reduction as well as loss coefficient reduction. 
TABLE 1.-CASCADE PARAMETERS

\begin{tabular}{|c|c|c|c|c|}
\hline $\begin{array}{c}\text { Axial } \\
\text { chord, } \\
C_{x} \\
{[\mathrm{~mm}]}\end{array}$ & $\begin{array}{c}\text { Pitch, } \\
L_{\phi} \\
{[\mathrm{mm}]}\end{array}$ & Span & $\begin{array}{c}\text { Inlet } \\
\text { flow } \\
\text { angle }\end{array}$ & $\begin{array}{c}\text { Exit } \\
\text { flow } \\
\text { angle }\end{array}$ \\
\hline 132.59 & 132.59 & 152.4 & $+29.7^{\circ}$ & $-65^{\circ}$ \\
\hline
\end{tabular}

TABLE 2.-PARAMETERS OF THE JETS CONFIGURATIONS

\begin{tabular}{|l|l|l|l|}
\hline \multicolumn{1}{|c|}{ Case } & \multicolumn{1}{c|}{ 1 Jet } & \multicolumn{1}{c|}{ 3 Jets } & \multicolumn{1}{c|}{ Jets } \\
\hline $\begin{array}{l}\text { Chordwise } \\
\text { location (\%Cx) }\end{array}$ & 23 & $\begin{array}{l}\text { 23 to 69 } \\
\text { (equally } \\
\text { spaced) }\end{array}$ & $\begin{array}{l}13 \text { to } 90 \\
\text { (equally } \\
\text { spaced) }\end{array}$ \\
\hline $\begin{array}{l}\text { Holes diameter } \\
\text { (mm) }\end{array}$ & 5 & 5 & 5 \\
\hline $\begin{array}{l}\text { Length to } \\
\text { diameter (L/D) } \\
\text { ratio }\end{array}$ & 1.5 & 1.5 & 1.5 \\
\hline $\begin{array}{l}\text { Plenum } \\
\text { pressure (kPa) }\end{array}$ & 36.942 & 36.942 & 36.942 \\
\hline $\begin{array}{l}\text { Plenum } \\
\text { temperature } \\
\text { (K) }\end{array}$ & 300 & 300 & 300 \\
\hline
\end{tabular}

TABLE 3.-SUMAMRY OF LEAKAGE AND LOSSES FOR ALL CASES

\begin{tabular}{|l|c|c|}
\hline \multicolumn{1}{|c|}{ Case } & $\begin{array}{c}\text { Tip leakage } \\
\text { mass flow }\end{array}$ & $\begin{array}{c}\text { Loss coefficient, } \\
\text { area averaged }\end{array}$ \\
\hline No Jets & 100 & 100 \\
\hline One Jet, Minus $30^{\circ}$ & 104 & 76 \\
\hline One Jet, $90^{\circ}$ & 96 & 67 \\
\hline (3) Jets, Plus $30^{\circ}$ & 95 & 82 \\
\hline (11) Jets, Plus $30^{\circ}$ & 88 & 105 \\
\hline
\end{tabular}




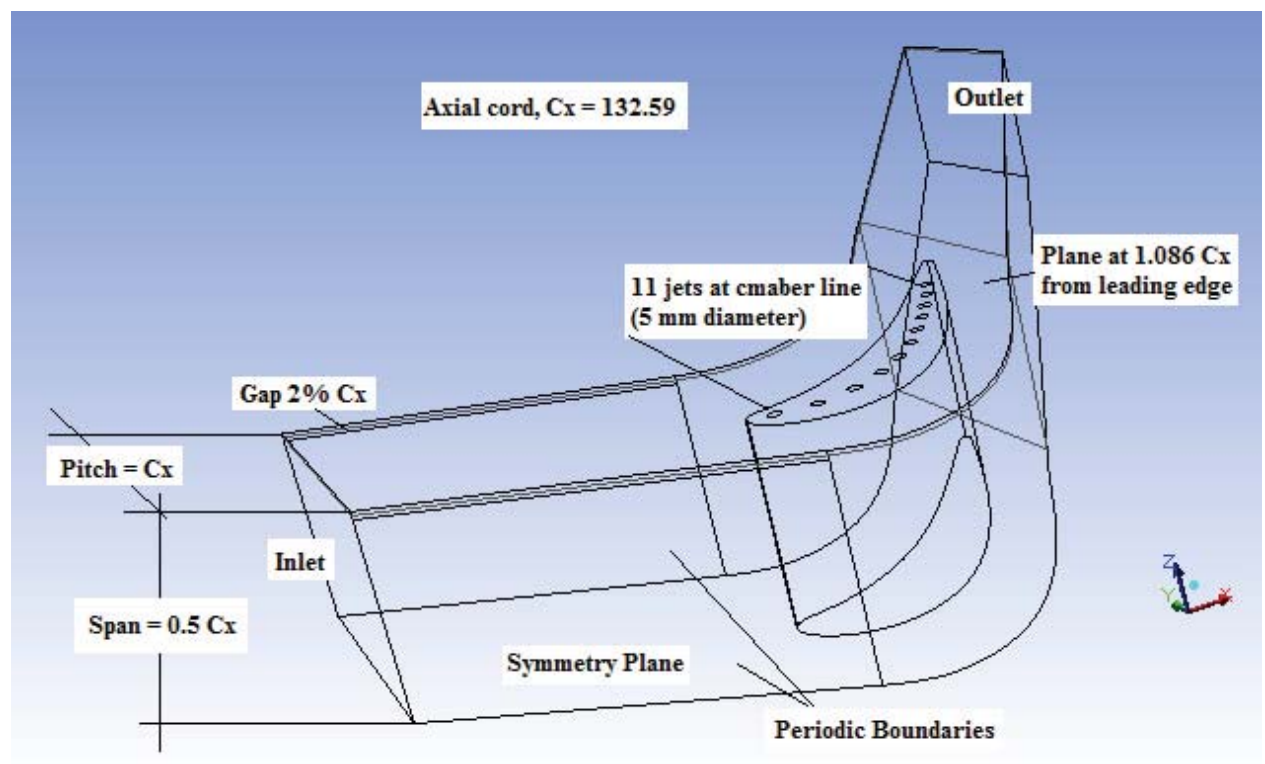

Figure 1.-Computation domain and boundary conditions.

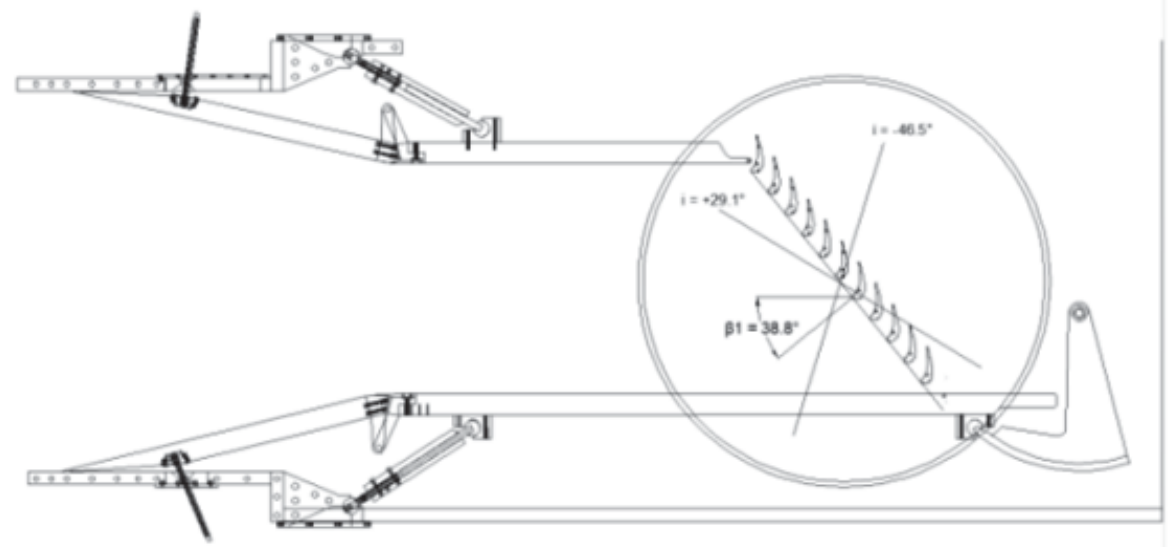

Figure 2. -Cascade Layout with EEE Blades at $\beta_{1}=38.8^{\circ}\left(I=+9.1^{\circ}\right)$. 


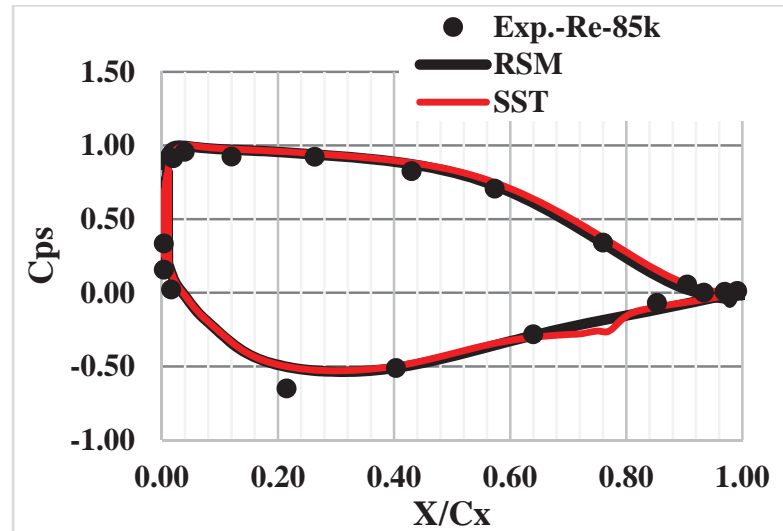

Figure 3(a).-Cps comparison, Exp. and CFD, $\mathrm{Re}=85,000, \mathrm{Z}=50 \%$, No Gap.

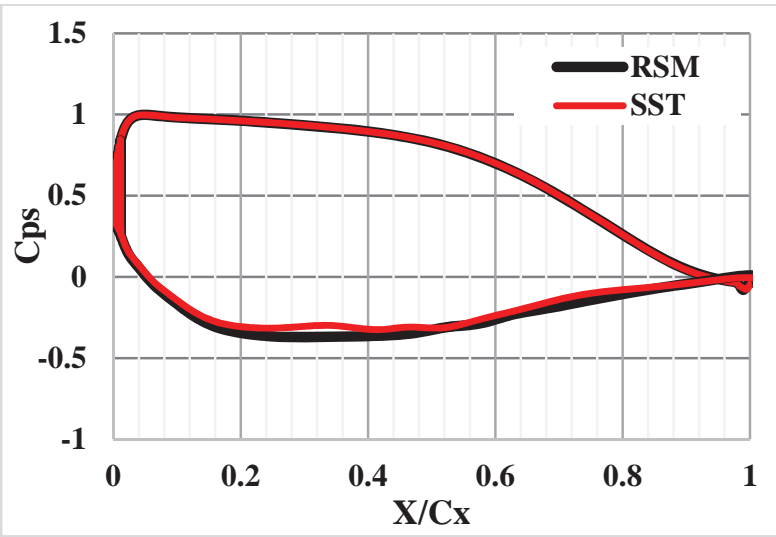

Figure 3(c).-Cps comparison Exp. and CFD, $R e=85,000, Z=97.5 \%$, No Gap.

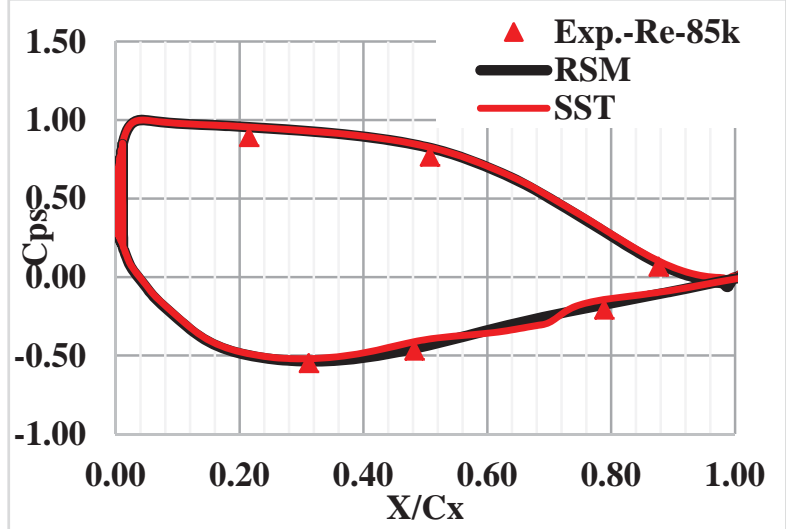

Figure 3(b).-Cps comparison, Exp. and CFD, $\mathrm{Re}=85,000, \mathrm{Z}=75 \%$, No Gap.

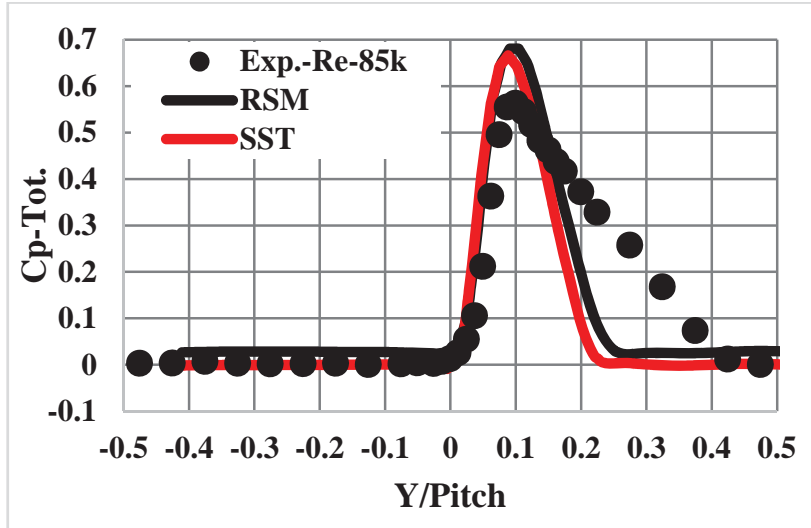

Figure 3(d).-Cp-total at $1.086 \mathrm{Cx}$, comparison, Exp. and CFD, $R e=85,000, Z=50 \%$, No Gap. 


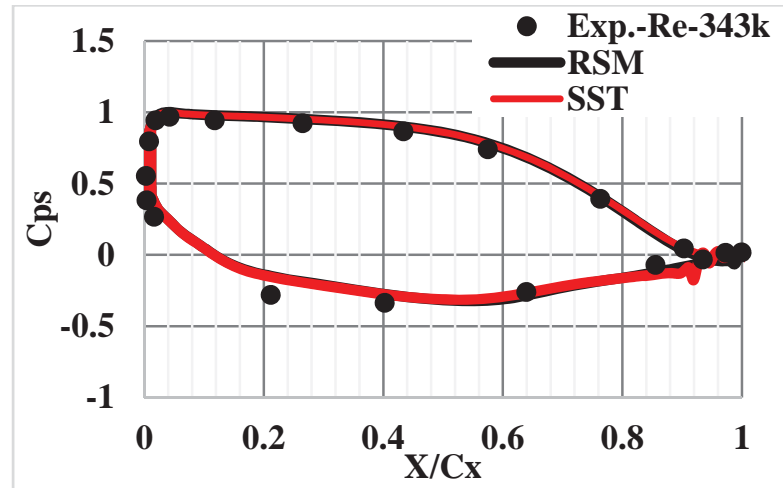

Figure 4(a).-Cps comparison, Exp. and CFD, $R e=343,000, Z=50 \%$, No Gap.

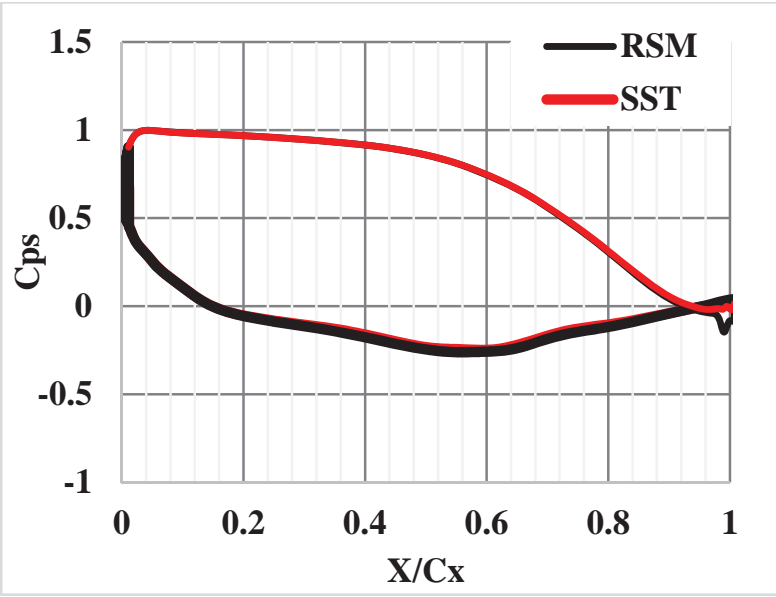

Figure 4(c).-Cps comparison, Exp. and CFD, $\operatorname{Re}=343,000, Z=97.5 \%$, No Gap.

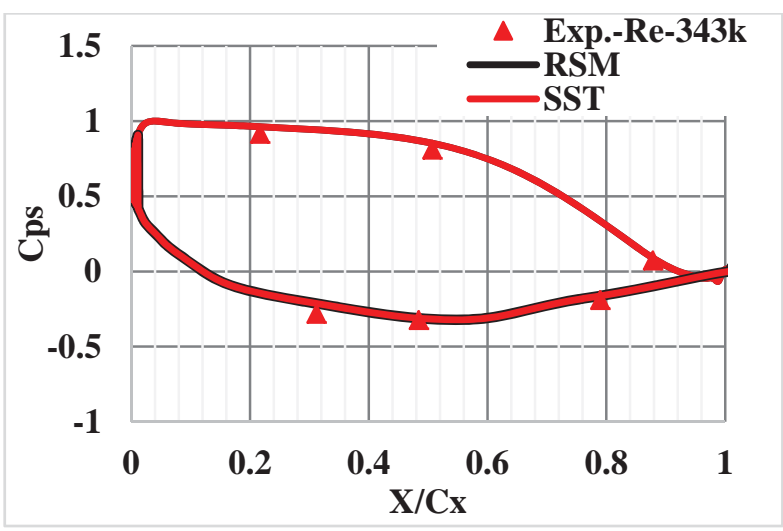

Figure 4(b).-Cps comparison, Exp. and CFD, $\mathrm{Re}=343,000, \mathrm{Z}=75 \%$, No Gap.

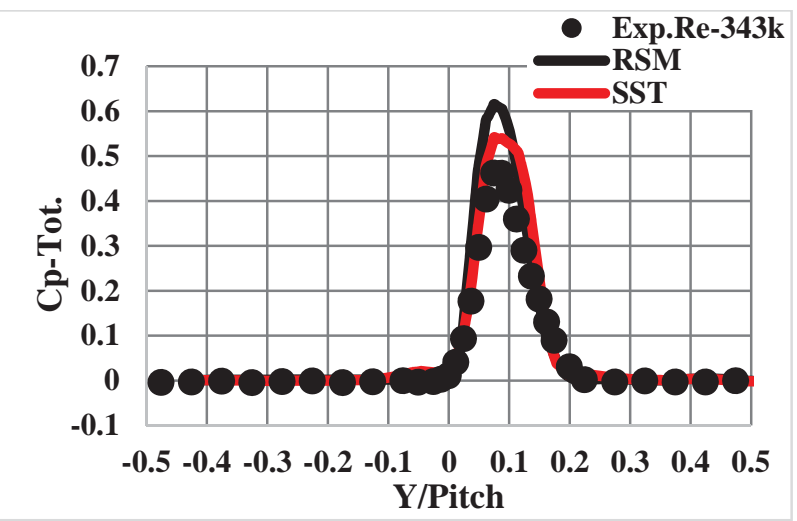

Figure 4(d).-Cp-total at $1.086 \mathrm{Cx}$, comparison, Exp. and CFD, $R e=343,000, Z=50 \%$, No Gap. 


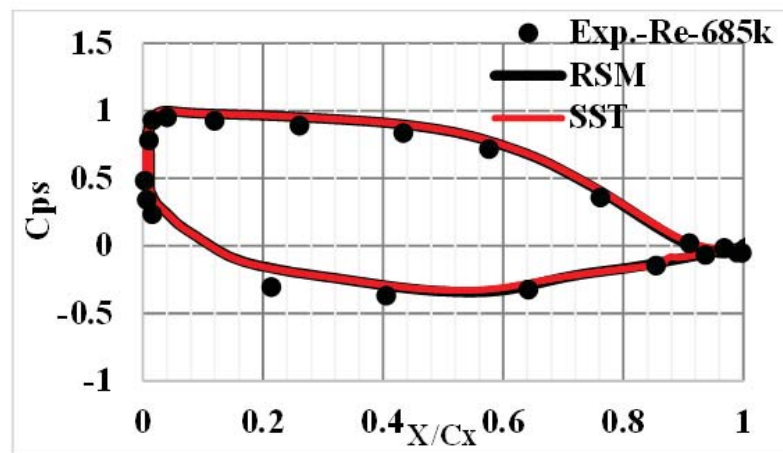

Figure 5(a).-Cps comparison, Exp. and CFD, $\operatorname{Re}=685,000, Z=50 \%$, No Gap.

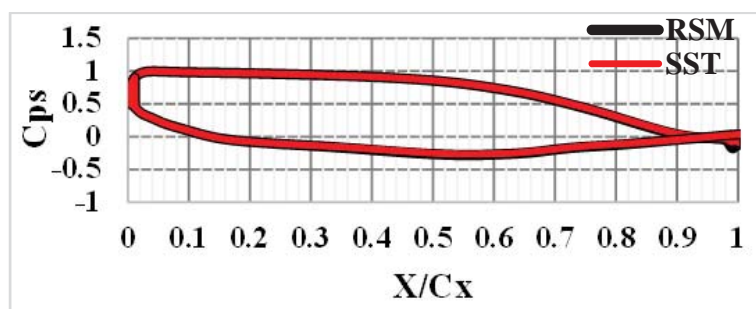

Figure 5(c).-Cps comparison, Exp. and CFD, Re = $685,000, Z=97.5 \%$, No Gap.

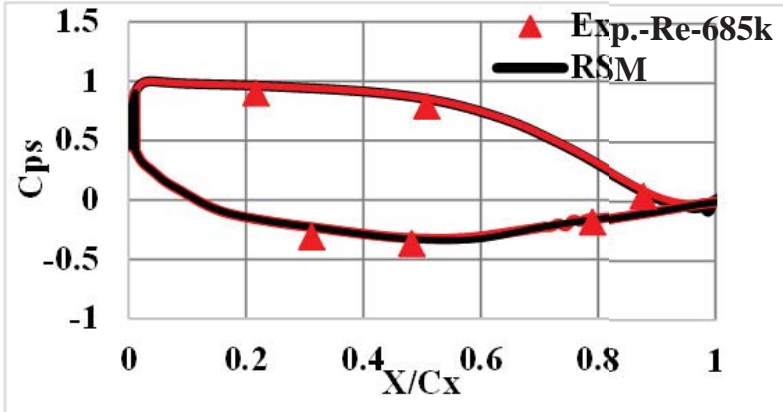

Figure 5(b).-Cps comparison, Exp. and CFD,

$\operatorname{Re}=685,000, Z=75 \%$, No Gap.

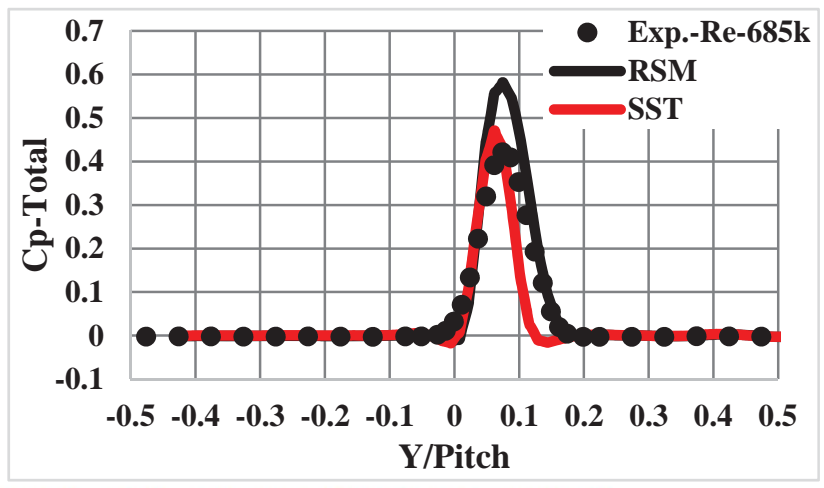

Figure 5(d).-Cp-total at $1.086 \mathrm{Cx}$, comparison, Exp. and CFD, $\operatorname{Re}=685,000, Z=50 \%$, No Gap.

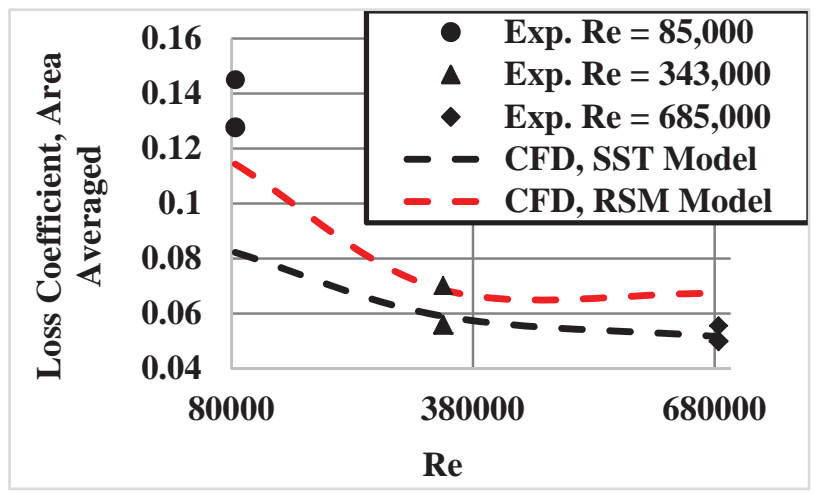

Figure 6.-Loss Coefficient, Area Averaged, for all cases examined, versus Re and RSM and SST turbulence models. 


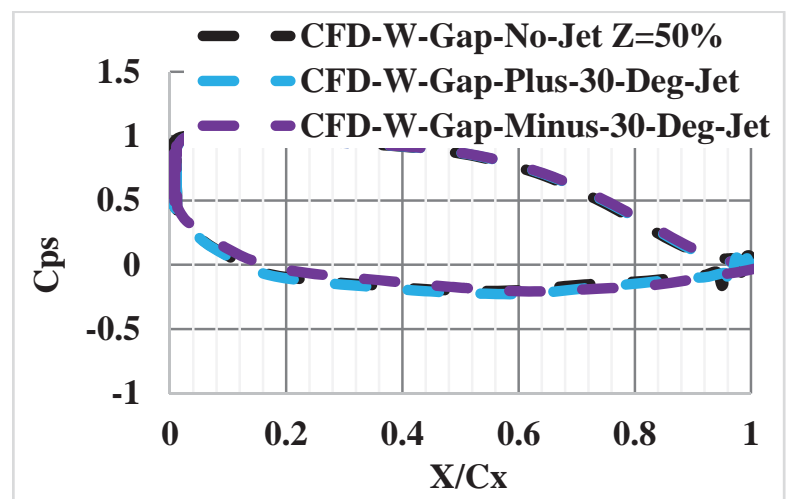

Figure 7(a).-Cps comparison, CFD, $R e=343,000$, $Z=50 \%$, No Jet, One Jet, Plus and Minus $30^{\circ}$.

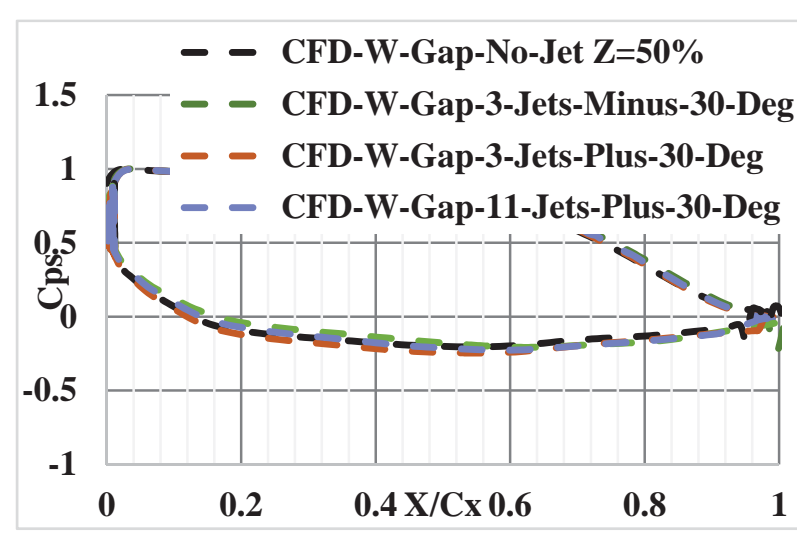

Figure 8(a).-Cps comparison, CFD, $R e=343,000, Z=$ $50 \%$, No Jet, 3 Jets, Plus and Minus 30 and 11 Jets Plus $30^{\circ}$.

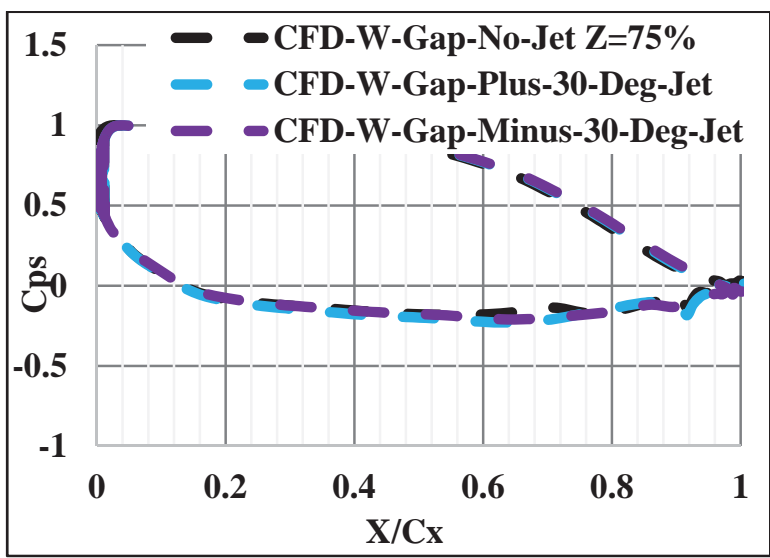

Figure 7(b).-Cps comparison, CFD, $R e=343,000$, $Z=75 \%$, No Jet, One Jet, Plus and Minus $30^{\circ}$.

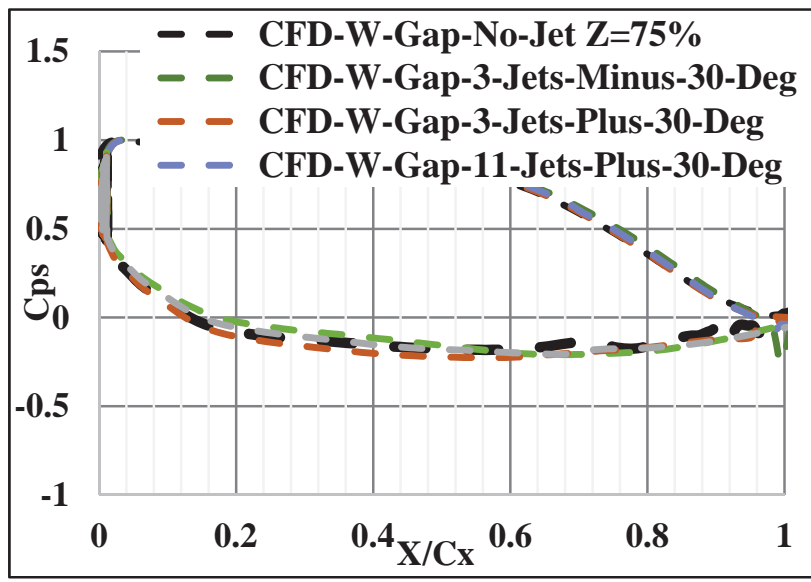

Figure 8(b).-Cps comparison, CFD, $R e=343,000$, $Z=75 \%$, No Jet, 3 Jets, Plus and Minus 30 and 11 Jets Plus $30^{\circ}$. 


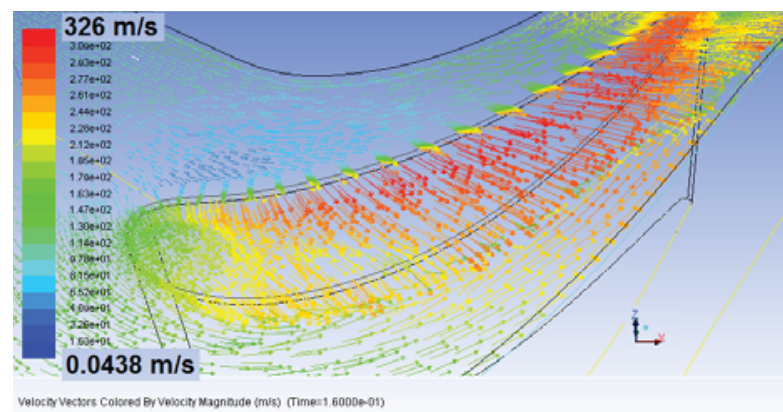

Figure 9(a).--Velocity vectors colored by the velocity magnitude, in a plane normal to $Z$ and mid-gap, $\operatorname{Re}=343,000$, No Jet.

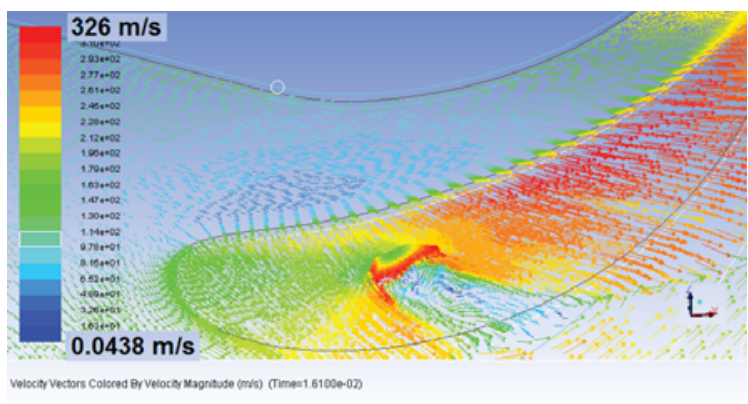

Figure 9(c).--Velocity vectors colored by the velocity magnitude, in a plane normal to $Z$ and mid-gap, $\operatorname{Re}=343,000$, One Jet, $90^{\circ}$.

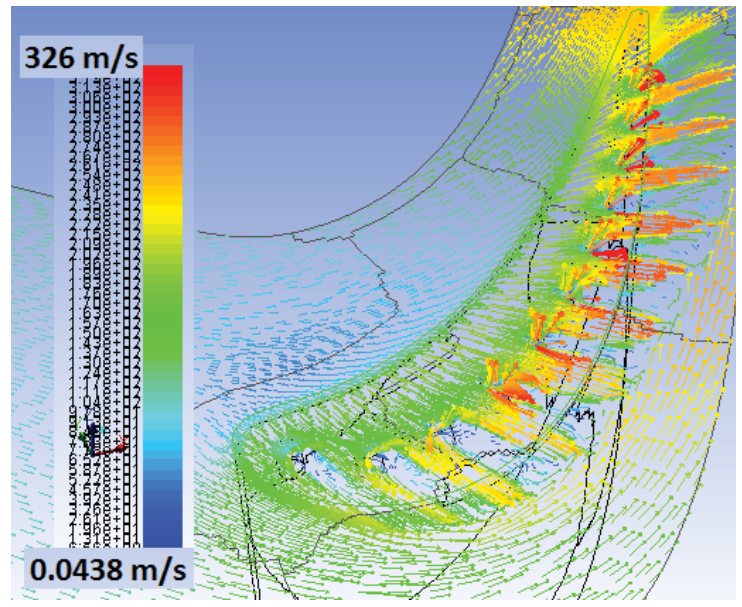

Figure 9(e).- -Velocity vectors colored by the velocity magnitude, in a plane normal to $Z$ and mid-gap, $\operatorname{Re}=343,000$, Eleven Jets, Plus $30^{\circ}$.

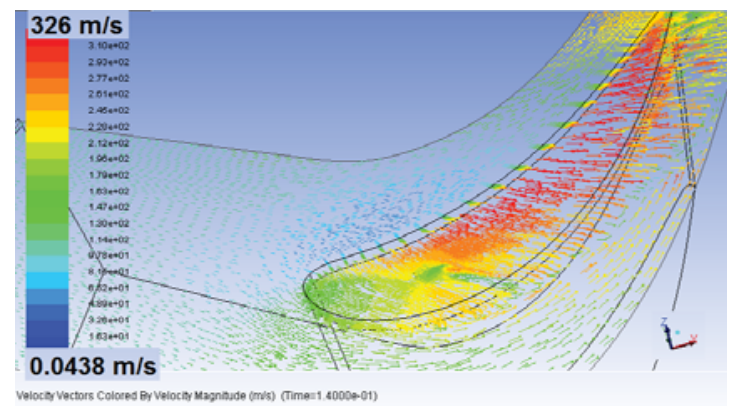

Figure 9(b).-Velocity vectors colored by the velocity magnitude, in a plane normal to $Z$ and mid-gap, $R e=343,000$, One Jet, Minus $30^{\circ}$.

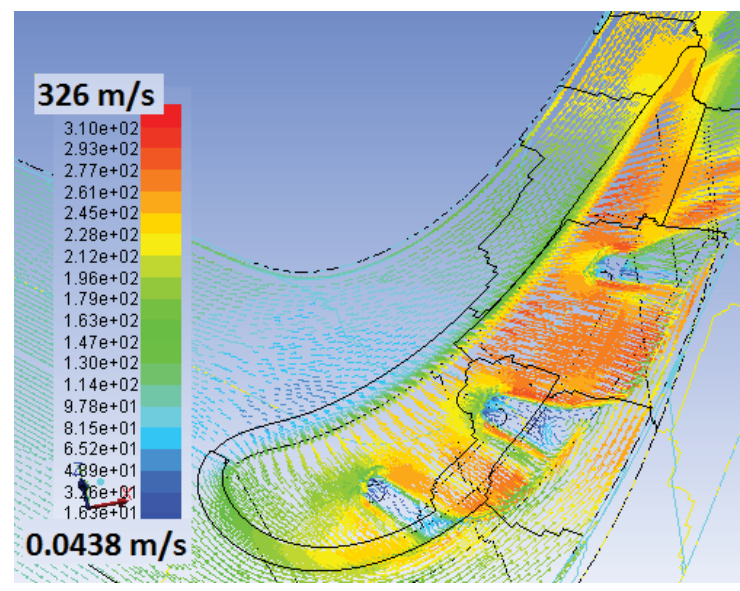

Figure 9(d).-Velocity vectors colored by the velocity magnitude, in a plane normal to $Z$ and mid-gap, $R e=343,000$, Three Jets, Plus $30^{\circ}$. 


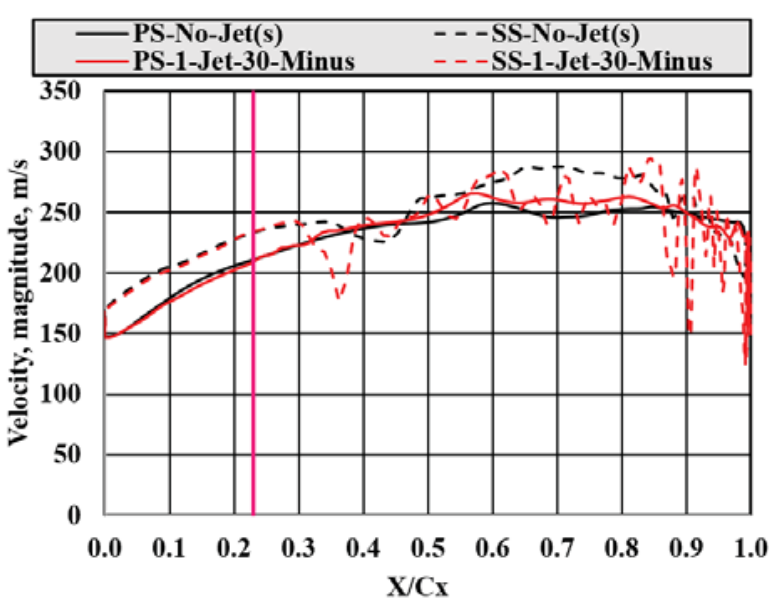

Figure 10(a).-Velocity magnitude versus $\mathrm{X} / \mathrm{Cx}$ at PS and SS for No jet and One Jet, Minus $30^{\circ}$.

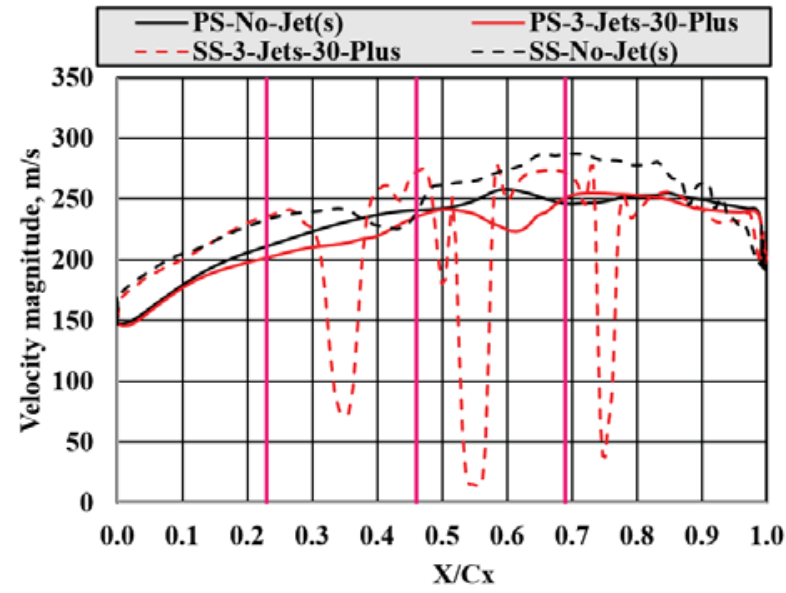

Figure 10(c).-Velocity magnitude versus $X / C x$ at PS and SS for No jet and Three Jets, Plus $30^{\circ}$.

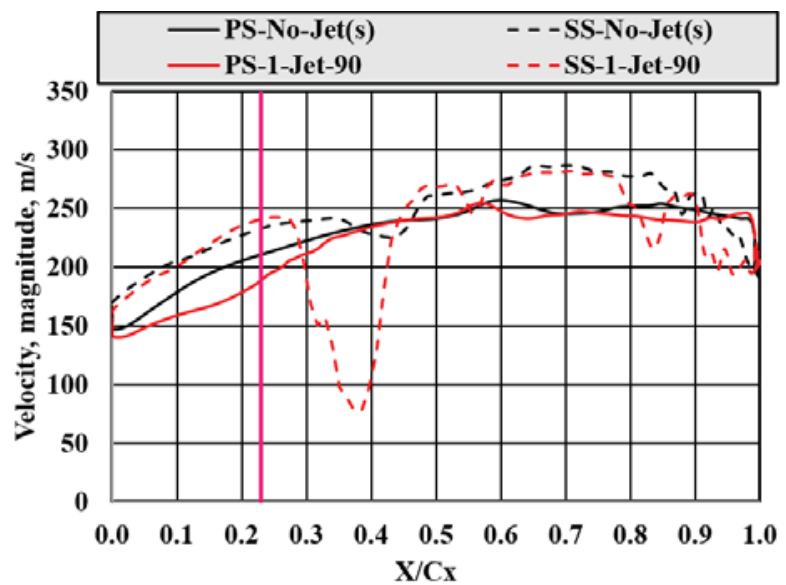

Figure 10(b).- Velocity magnitude versus $\mathrm{X} / \mathrm{Cx}$ at PS and SS for No jet and One Jet, $90^{\circ}$.

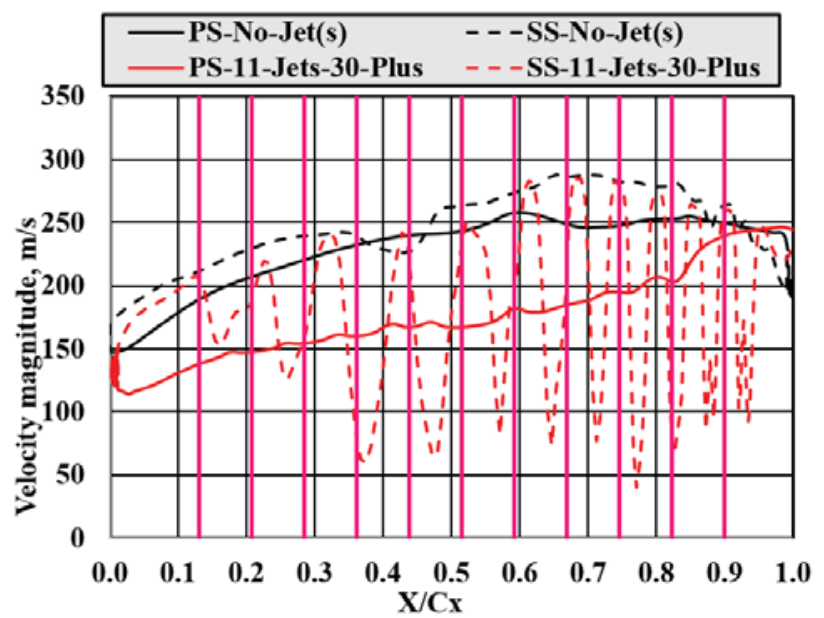

Figure $10(d)$.- - Velocity magnitude versus $\mathrm{X} / \mathrm{Cx}$ at PS and SS for No jet and Eleven Jets, Plus $30^{\circ}$.

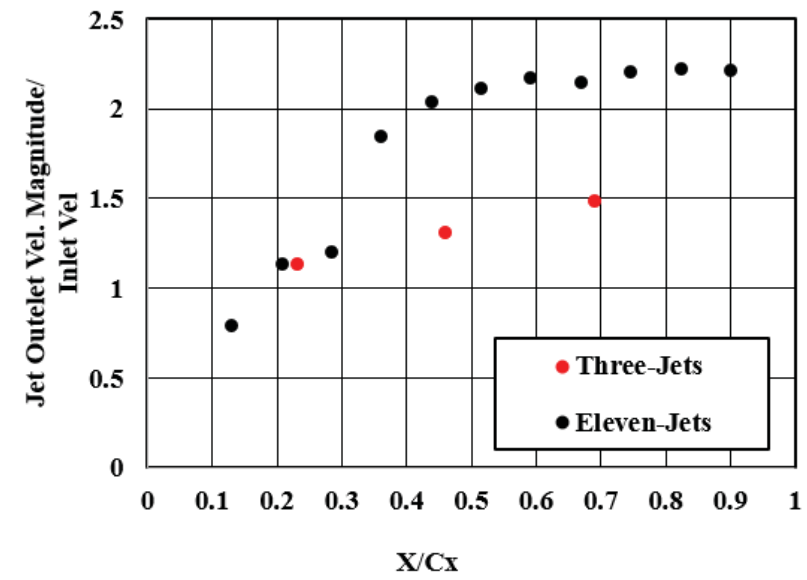

Figure 11.-Jets velocity magnitude/ Inlet velocity versus $\mathrm{X} / \mathrm{Cx}$ for Three and Eleven Jets, Plus $30^{\circ}$. 


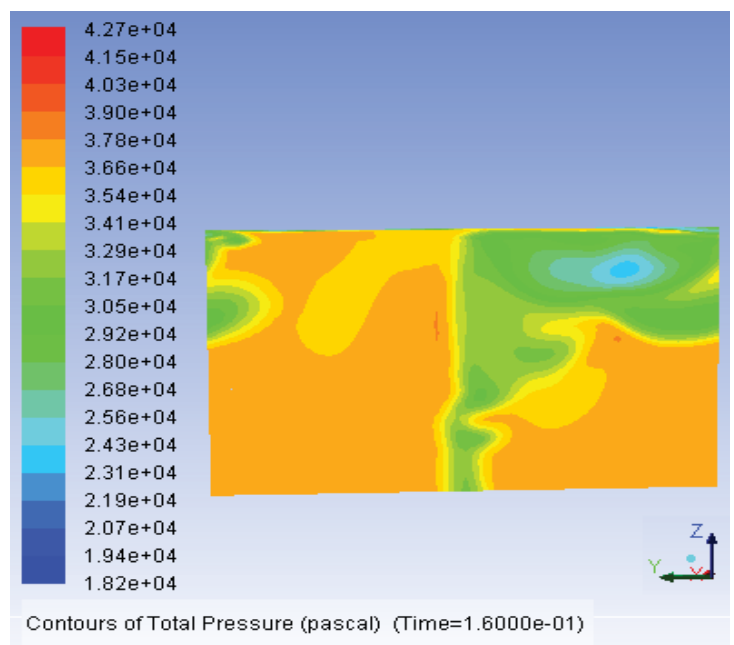

Figure 12(a).-Contours of the total pressure at $1.086 \mathrm{Cx}$ (from leading edge), for No jet(s).

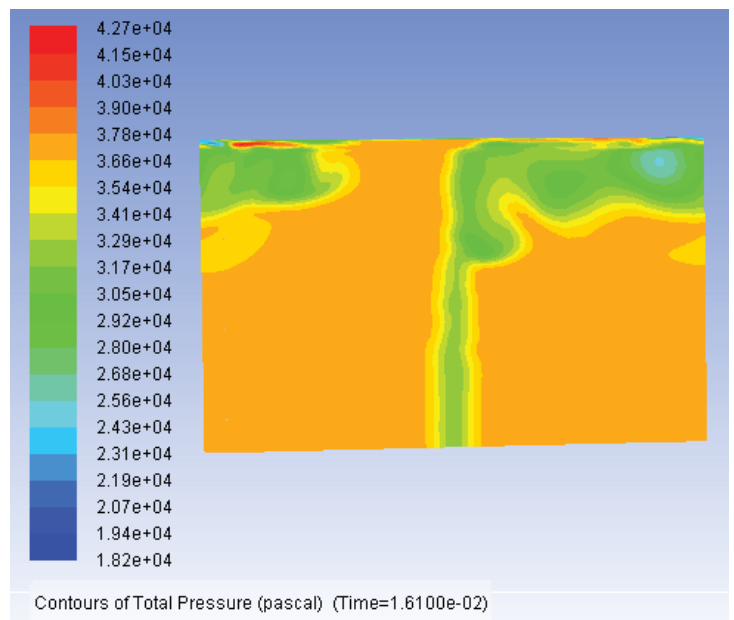

Figure 12(c).-Contours of the total pressure at $1.086 \mathrm{Cx}$ (from leading edge), for One Jet, $90^{\circ}$.

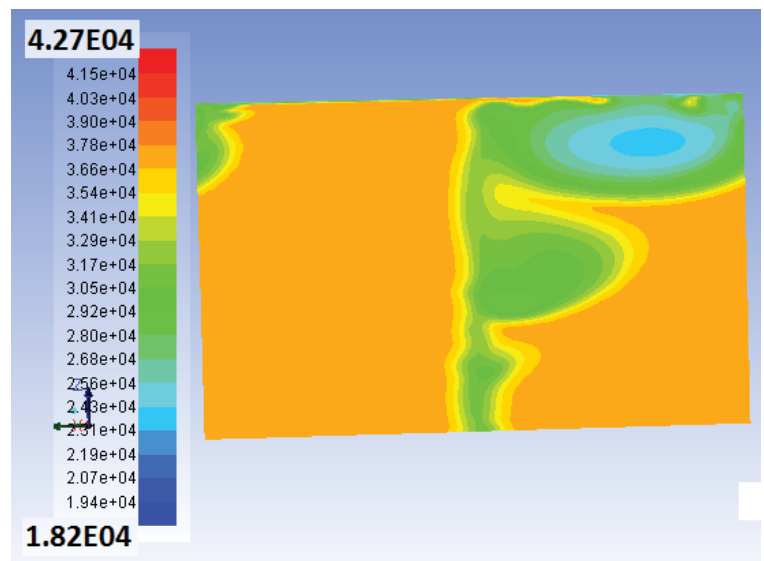

Figure 12(e).-Contours of the total pressure at $1.086 \mathrm{Cx}$ (from leading edge), for Eleven Jets, Minus $30^{\circ}$.

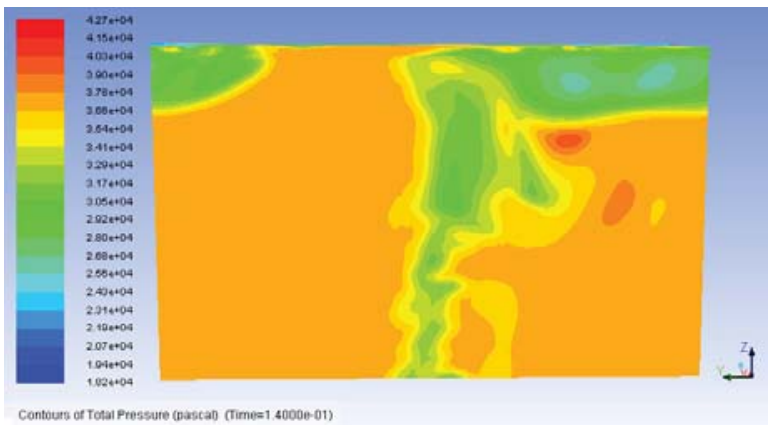

Figure $12(\mathrm{~b})$.-Contours of the total pressure at $1.086 \mathrm{Cx}$ (from leading edge), for One Jet, Minus $30^{\circ}$.

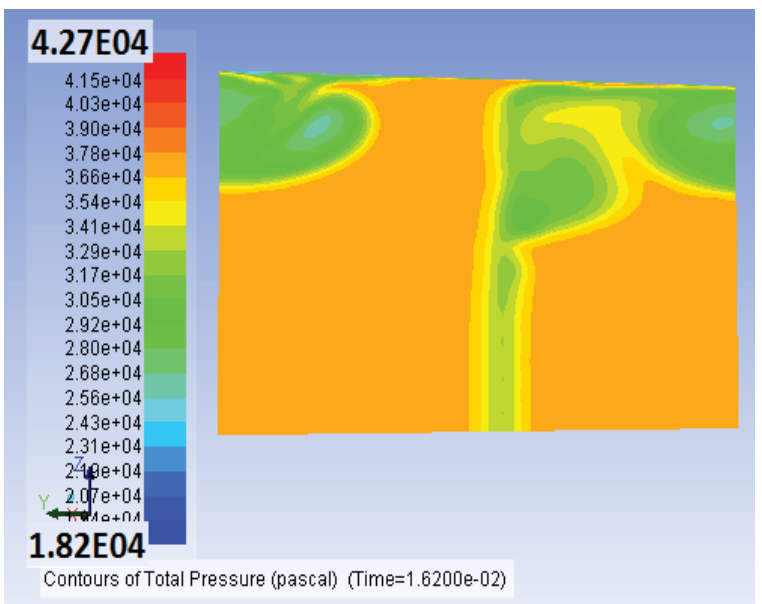

Figure $12(\mathrm{~d})$. - Contours of the total pressure at $1.086 \mathrm{Cx}$ (from leading edge), for Three Jets, Minus $30^{\circ}$. 


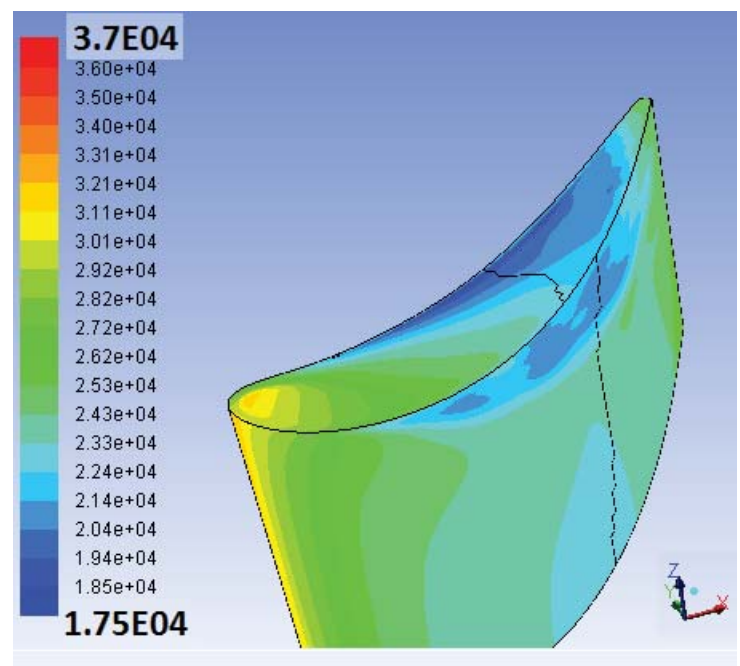

Contours of Static Pressure (pascal) (Time $=1.6000 \mathrm{e}-01$ )

Figure 13(a).-Contours of the static pressure at the blade top and SS, for No jet(s).

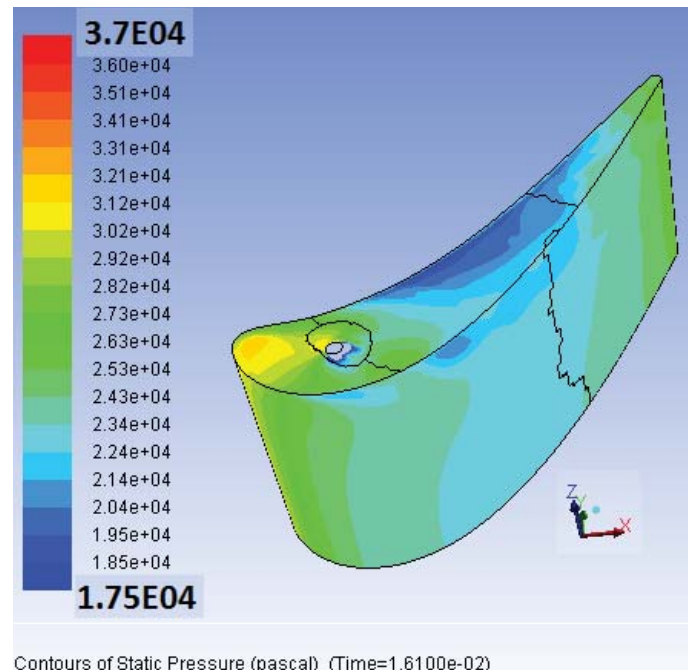

Figure 13(c).-Contours of the static pressure at the blade top and SS, for One jet, $90^{\circ}$.

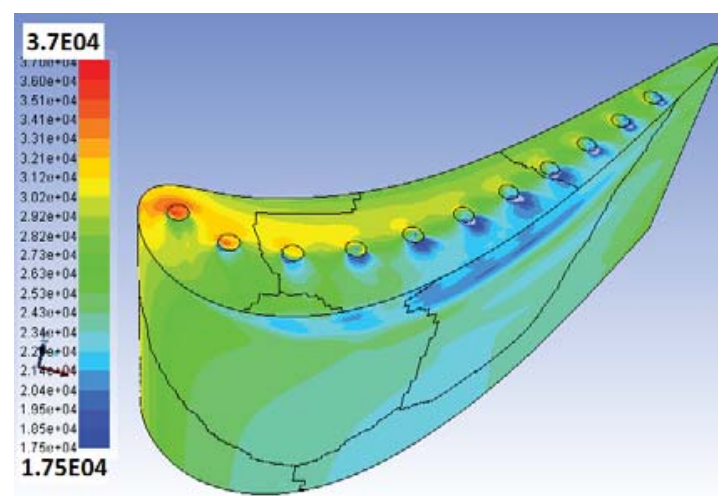

Figure 13(e).-Contours of the static pressure at the blade top and SS, for Eleven jets, Plus $30^{\circ}$.

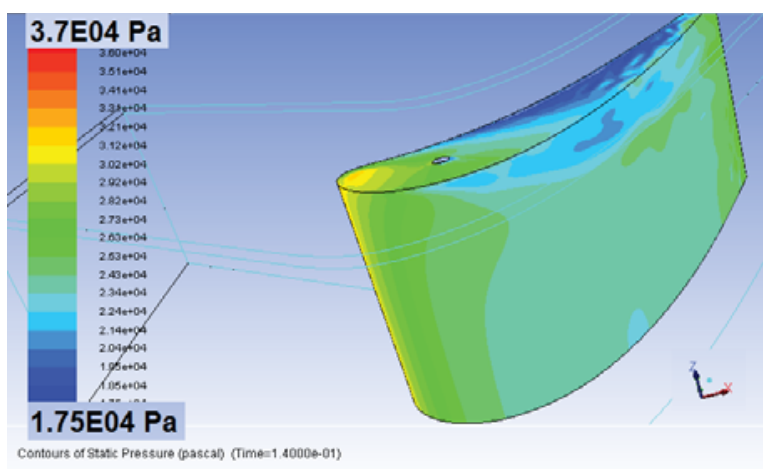

Figure 13(b).-Contours of the static pressure at the blade top and SS, for One jet, Minus $30^{\circ}$.

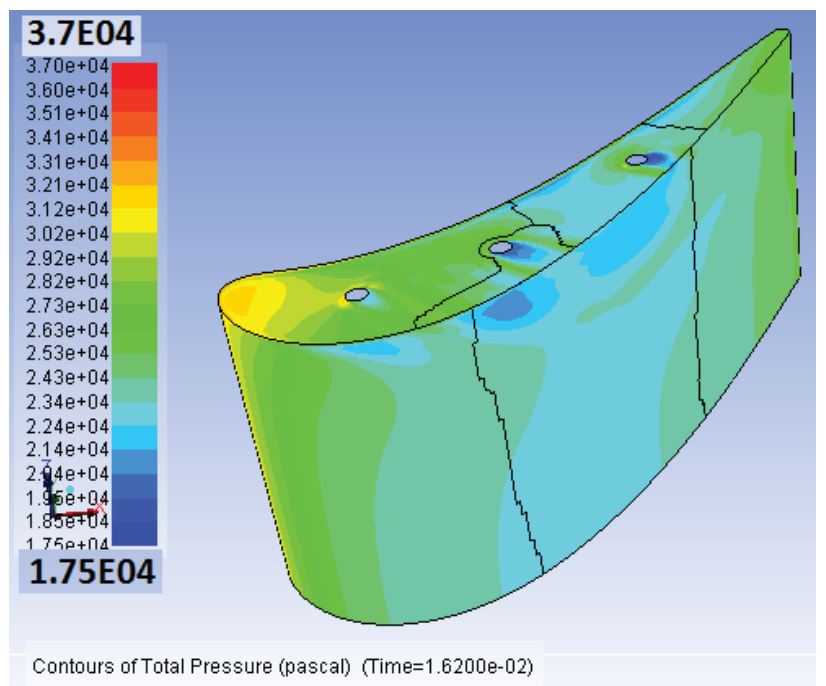

Figure 13(d).-Contours of the static pressure at the blade top and SS, for Three jets, Plus $30^{\circ}$. 


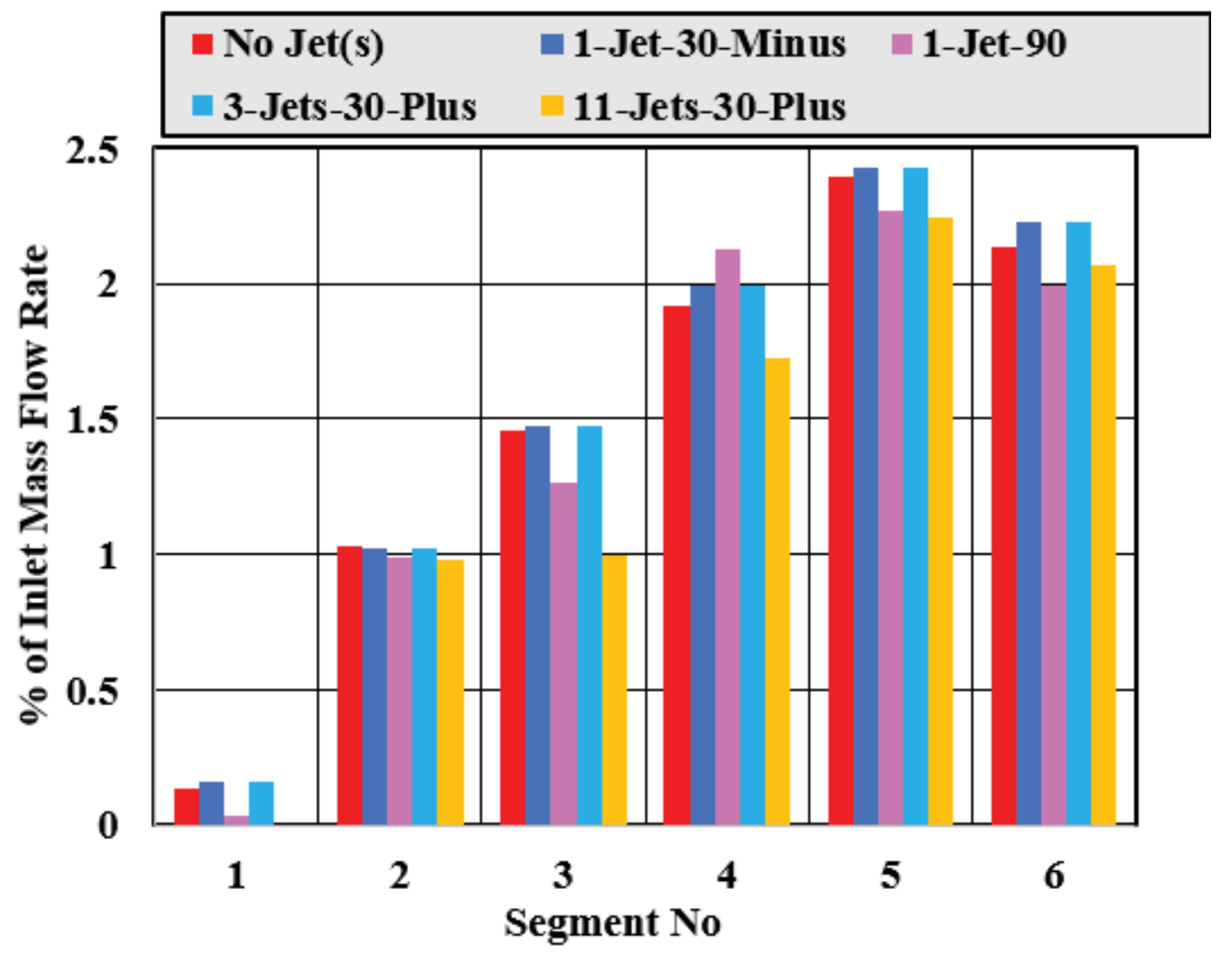

Figure 14.-Tip leakage mass flow as percent of total inlet mass flow for (6) segments along the suction side of the gap, $\operatorname{Re}=343,000$, No Jets, One Jet Minus $30^{\circ}$, One Jet $90^{\circ}$, Three Jets, Plus $30^{\circ}$, and Eleven Jets, Plus $30^{\circ}$.

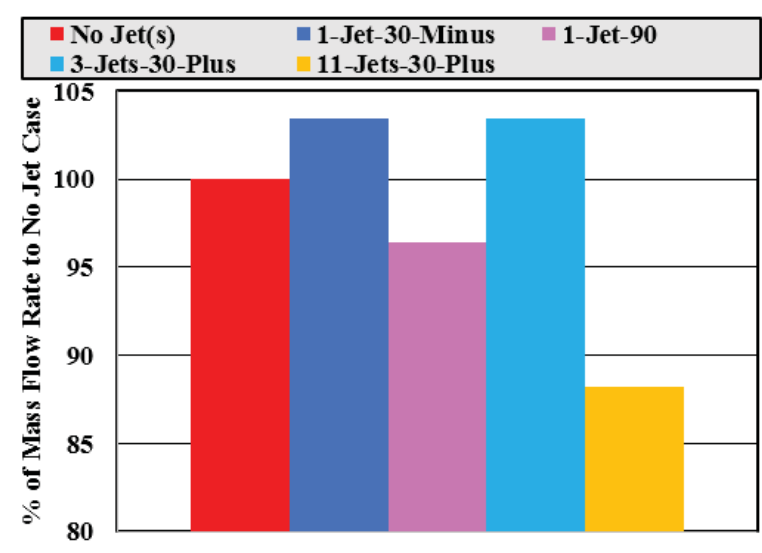

Figure 15.-Total tip leakage mass flow as percent of the No Jet case, $R e=343,000$, No Jets, One Jet Minus $30^{\circ}$, One Jet $90^{\circ}$, Three Jets, Plus $30^{\circ}$, and Eleven Jets, Plus $30^{\circ}$.

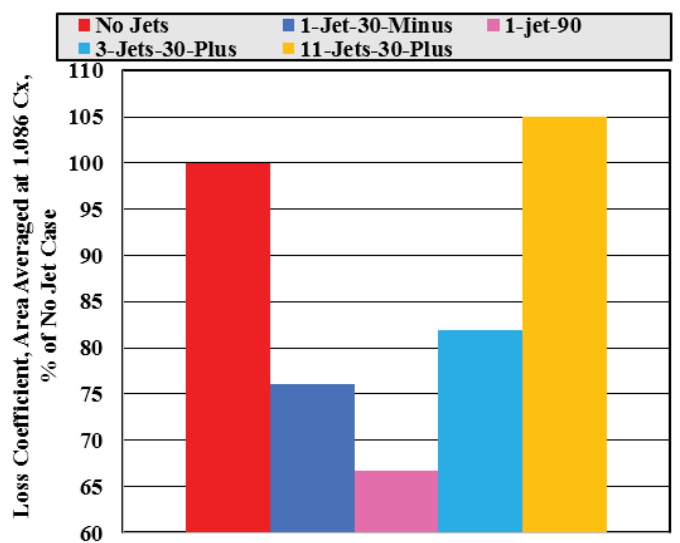

Figure 16.-Loss coefficient, area averaged at $1.086 \mathrm{Cx}$ as percent of the No Jet case, $\mathrm{Re}=$ 343,000 , No Jets, One Jet Minus $30^{\circ}$, One Jet $90^{\circ}$, Three Jets, Plus $30^{\circ}$, and Eleven Jets, Plus $30^{\circ}$. 


\section{References}

1. Bunker, R.S., "A Review of Turbine Blade Tip Heat Transfer," Annals of the New York Academy of Science, Vol. 934, pp 64-79, January 2006.

2. Glezer, B., Harvey, N.W., Camci, C., Bunker, R.S., Ameri, A.A., "Turbine Blade Tip Design and Tip Clearance Treatment," notes from von Karman Lecture Series 2004, June 2004.

3. Zhou, C., and Hodson, H., "The Tip Leakage flow of an Unshrouded High Pressure Turbine Blade With Tip Cooling," ASME-GT2009-59637, June 2009.

4. Ameri, A.A., Steinthorsson, E., Rigby, D.L., "Effect of Squealer Tip on Rotor Heat Transfer and Efficiency," Journal of Turbomachinery, Vol. 120, pp 753-759, October 1998.

5. Ameri, A.A., Steinthorsson, E., Rigby, D.L., "Effects of Tip Clearance and Casing Recess on Heat Transfer and Stage Efficiency in Axial Turbines," Journal of Turbomachinery, Vol. 121, pp 683693, October 1999.

6. Hofer, T., Arts, T., "Aerodynamic Investigation of the Tip Leakage Flow for Blades With Different Tip Squealer Geometries at Transonic Conditions,” ASMEGT2009-59909, June 2009.

7. Krishnababu, S.K., Dawes, W.N., Hodson, H.P., Lock, G.D., Hannis, J., Whitney, C., “AeroThermal Investigations of Tip Leakage Flow in Axial Flow Turbines, Part II -Effect of Relative Casing Motion," ASME 2007-GT-27957, May 2007.

8. Shyam V., Ameri A., Chen J.P., "Analysis of Unsteady Tip and Endwall Heat Transfer in a Highly Loaded Transonic Turbine Stage," Proceedings of the ASME TURBO Expo 2010, Glasgow, June 2010, J. Turbomach. 134, 041022 (2012).

9. Shyam, V., Ameri, A., "Comparison of Various Supersonic Turbine Tip Designs to Minimize Aerodynamic Loss and Tip Heating." NASA/TM-2012-217607.

10. Wheeler, A., Atkins, N., He, L., "Turbine Blade Tip Heat Tansfer in Low Speed and High Speed Flows," J.Turbomachinery, Vol. 133, No. 42011.

11. N. M. Rao and C. Camci, "Axial turbine tip desensitization by injection from a tip trench-part 1: effect of injection mass flow rate," in Proceedings of the ASME Turbo Expo: Power for Land, Sea and Air Conference, pp. 1075-1088, 2004, ASME paper no. GT2004-53256.

12. Couch, E., Christophel, J., Hohlfeld, E., Thole, K., "Comparison of Measurements and Predictions for Blowing from a Turbine Blade Tip," Journal of Propulsion and Power, Vol. 21, No.2, MarchApril 2005.

13. Bogard, D., and Thole, K., 2006, "Gas Turbine Film Cooling," Journal of Propulsion and Power, 22(2), 249 270, DOI:10.2514/1.18034.

14. Canelli, C., Castelanelli, M., Luccoli, R., Abba, L., Corcoruto, S., Traverso, S., "Numerical Prediction of Film Cooling on the Squealer Tip of Gas Turbine Blade," $59^{\text {th }}$ Congresso Annuale ATI - Geneva 2004.

15. Ibrahim, M.B., Kartuzova, O. and Volino, R.J., "Experimental and Computational Investigations of Separation and Transition on a Highly Loaded Low Pressure Turbine Airfoil: Part 1 - Low Freestream Turbulence Intensity," ASME Paper IMECE2008-68879, 2008.

16. Ibrahim, M.B., Kartuzova, O., Doucet, D.J. and Volino, R.J. "Les Flow Control Simulations For Highly Loaded Low Pressure Turbine Airfoil (L1a) Using Pulsed Vortex Generator Jets," ASME Paper GT2010-23015, 2010.

17. McVetta, A., Giel, P., Welch, G., "Aerodynamic Investigation of Incidence Angle Effects in a Large Scale Transonic Turbine Cascade," AIAA 2012-3879, 48th AIAA/ASME/SAE/ASEE Joint Propulsion Conference \& Exhibit. July.

18. ANSYS FLUENT Documentation, 2009. 


\begin{tabular}{|c|c|c|c|c|c|}
\hline \multicolumn{5}{|c|}{ REPORT DOCUMENTATION PAGE } & $\begin{array}{l}\text { Form Approved } \\
\text { OMB No. 0704-0188 }\end{array}$ \\
\hline \multicolumn{6}{|c|}{$\begin{array}{l}\text { The public reporting burden for this collection of information is estimated to average } 1 \text { hour per response, including the time for reviewing instructions, searching existing data sources, gathering and } \\
\text { maintaining the data needed, and completing and reviewing the collection of information. Send comments regarding this burden estimate or any other aspect of this collection of information, including } \\
\text { suggestions for reducing this burden, to Departm ent of Defense, Washington Headquarters Services, Directorate for Information Operations and Reports (0704-0188), } 1215 \text { Jefferson Davis Highway, Suite } \\
1204 \text {, Arlington, VA } 22222-4302 \text {. Respondents should be aware that notwithstanding any other provision of law, no person shall be subject to any penalty for failing to comply with a collection of information if it } \\
\text { does not display a currently yalid OMB control Inumber. } \\
\text { PLEASE DO NOT RETURN YOUR FORM TO THE ABOVE ADDRESS. }\end{array}$} \\
\hline \multicolumn{2}{|c|}{$\begin{array}{l}\text { 1. REPORT DATE (DD-MM-YYYY) } \\
01-11-2014\end{array}$} & \multicolumn{3}{|c|}{$\begin{array}{l}\text { 2. REPORT TYPE } \\
\text { Technical Memorandum }\end{array}$} & 3. DATES COVERED (From - To) \\
\hline \multicolumn{5}{|c|}{$\begin{array}{l}\text { 4. TITLE AND SUBTITLE } \\
\text { Computational Investigation of Novel Tip Leakage Mitigation Methods for High } \\
\text { Pressure Turbine Blades }\end{array}$} & 5c. PROGRAM ELEMENT NUMBER \\
\hline \multirow{2}{*}{\multicolumn{5}{|c|}{$\begin{array}{l}\text { 6. AUTHOR(S) } \\
\text { Ibrahim, Mounir; Gupta, Abhinav; Shyam, Vikram }\end{array}$}} & 5d. PROJECT NUMBER \\
\hline & & & & & $\begin{array}{l}\text { 5f. WORK UNIT NUMBER } \\
\text { WBS 473452.02.03.05.04.02.01 }\end{array}$ \\
\hline \multicolumn{5}{|c|}{$\begin{array}{l}\text { 7. PERFORMING ORGANIZATION NAME(S) AND ADDRESS(ES) } \\
\text { National Aeronautics and Space Administration } \\
\text { John H. Glenn Research Center at Lewis Field } \\
\text { Cleveland, Ohio 44135-3191 }\end{array}$} & $\begin{array}{l}\text { 8. PERFORMING ORGANIZATION } \\
\text { REPORT NUMBER } \\
\text { E-18962 }\end{array}$ \\
\hline \multirow{2}{*}{\multicolumn{5}{|c|}{$\begin{array}{l}\text { 9. SPONSORING/MONITORING AGENCY NAME(S) AND ADDRESS(ES) } \\
\text { National Aeronautics and Space Administration } \\
\text { Washington, DC 20546-0001 }\end{array}$}} & $\begin{array}{l}\text { 10. SPONSORING/MONITOR'S } \\
\text { ACRONYM(S) } \\
\text { NASA }\end{array}$ \\
\hline & & & & & $\begin{array}{l}\text { 11. SPONSORING/MONITORING } \\
\text { REPORT NUMBER } \\
\text { NASA/TM-2014-218494 }\end{array}$ \\
\hline \multicolumn{6}{|c|}{$\begin{array}{l}\text { 12. DISTRIBUTION/AVAILABILITY STATEMENT } \\
\text { Unclassified-Unlimited } \\
\text { Subject Categories: } 07 \text { and } 64 \\
\text { Available electronically at http://www.sti.nasa.gov } \\
\text { This publication is available from the NASA Center for AeroSpace Information, 443-757-5802 }\end{array}$} \\
\hline \multicolumn{6}{|c|}{ 13. SUPPLEMENTARY NOTES } \\
\hline \multicolumn{6}{|c|}{$\begin{array}{l}\text { 14. ABSTRACT } \\
\text { This paper presents preliminary findings on a possible approach to reducing tip leakage losses. In this paper a computational study was conducted on the Energy Efficient } \\
\text { Engine (EEE) High Pressure Turbine (HPT) rotor tip geometry using the commercial numerical solver ANSYS FLUENT. The flow solver was validated against aerodynamic } \\
\text { data acquired in the NASA Transonic Turbine Blade Cascade facility. The scope of the ongoing study is to computationally investigate how the tip leakage and overall blade } \\
\text { losses are affected by (1) injection from the tip near the pressure side, (2) injection from the tip surface at the camber line, and (3) injection from the tip surface into the tip } \\
\text { separation bubble. The objective is to identify the locations on the tip surface at which to place appropriately configured blowing keeping in mind the film cooling application } \\
\text { of tip blowing holes. The validation was conducted at Reynolds numbers of } 85,000,343,000 \text {, and } 685,000 \text { and at engine realistic flow conditions. The coolant injection } \\
\text { simulations were conducted at a Reynolds number of } 343,000 \text { based on blade chord and inlet velocity and utilized the SST turbulence model in FLUENT. The key parameters } \\
\text { examined are the number of jets, jet angle and jet location. A coolant to inlet pressure ratio of } 1.0 \text { was studied for angles of }+30^{\circ},-30^{\circ} \text {, and } 90^{\circ} \text { to the local free stream on the } \\
\text { tip. For the } 3 \text { hole configuration, } 3 \text { holes spaced } 3 \text { hole diameters apart with length to diameter ratio of } 1.5 \text { were used. A simulation including } 11 \text { holes along the entire mean } \\
\text { camber line is also presented ( } 30^{\circ} \text { toward suction side). In addition, the effect of a single hole is also compared to a flat tip with no injection. The results provide insight into tip } \\
\text { flow control methods and can be used to guide further investigation into tip flow control. As noted in past research it is concluded that reducing leakage flow is not necessarily } \\
\text { synonymous with reducing losses due to leakage. }\end{array}$} \\
\hline \multicolumn{6}{|c|}{$\begin{array}{l}\text { 15. SUBJECT TERMS } \\
\text { Leakage; Blowing; Supersonic; Turbine; Engine; Camber; Hole geometry; Turbulence models; Aerodynamics }\end{array}$} \\
\hline \multicolumn{3}{|c|}{ 16. SECURITY CLASSIFICATION OF: } & 17. LIMITATION OF & 18. NUMBER & 19a. NAME OF RESPONSIBLE PERSON \\
\hline \multirow{2}{*}{$\begin{array}{l}\text { a. REPORT } \\
\text { U }\end{array}$} & \multirow{2}{*}{$\begin{array}{l}\text { b. ABSTRACT } \\
\text { U }\end{array}$} & \multirow{2}{*}{$\begin{array}{l}\text { c. THIS PAGE } \\
\text { U }\end{array}$} & ABSTRACT & OF & STI Help Desk (email:help@sti.nasa.gov) \\
\hline & & & & 26 & $\begin{array}{l}\text { 19b. TELEPHONE NUMBER (include area code) } \\
443-757-5802\end{array}$ \\
\hline
\end{tabular}



